\title{
Greenhouse Gas Emissions from Housing and Manure Management Systems at Confined Livestock Operations
}

\author{
Md Saidul Borhan, Saqib Mukhtar, Sergio Capareda and Shafiqur Rahman
}

Additional information is available at the end of the chapter

http://dx.doi.org/10.5772/51175

\section{Introduction}

As the name implies, the gases that assist in capturing heat in the atmosphere are termed as greenhouse gases (GHGs). The continuously rising concentrations of these gasses are believed to work against nature's natural process, trapping more heat than what is needed leading to an increase of earth's climate temperature. Livestock production operations contribute both directly and indirectly to climate change through the emissions of greenhouse gases such as carbon dioxide $\left(\mathrm{CO}_{2}\right)$, methane $\left(\mathrm{CH}_{4}\right)$ and nitrous oxide $\left(\mathrm{N}_{2} \mathrm{O}\right)$. Generally, swine and ruminant livestock operations, especially dairy cows and beef cattle, contribute to the production of GHGs mainly $\mathrm{CH}_{4}, \mathrm{~N}_{2} \mathrm{O}$, and $\mathrm{CO}_{2}$ in the environment. The $\mathrm{CH}_{4}, \mathrm{CO}_{2}$, and $\mathrm{N}_{2} \mathrm{O}$ are considered as direct greenhouse gases. The indirect GHGs include carbon monoxide (CO), oxides of nitrogen (NOx), and non-methane volatile organic compound (NMVOCs). Characterization and quantification of $\mathrm{N}_{2} \mathrm{O}$ and $\mathrm{CH}_{4}$ emitted from livestock operations are important because these gases are believed to play a major role in the increase of Earth's temperature. During the last two hundred and fifty years, anthropogenic activities, including demanding agricultural production, have increased the global atmospheric concentration of GHG, namely $\mathrm{CO}_{2}, \mathrm{CH}_{4}$, and $\mathrm{N}_{2} \mathrm{O}$ by 36,148 , and $18 \%$, respectively [1]. Total greenhouse gas (GHG) emissions in the US increased by $14.7 \%$ from 1990 to 2006. All agricultural sources combined were estimated to have generated $454 \mathrm{Tg}$ $\left(10^{12} \mathrm{~g}\right)$ of $\mathrm{CO}_{2}$ equivalents in the U.S. during 2006 [2]. The $\mathrm{CH}_{4}$ emissions from enteric fermentation and manure management represent about 25 and $8 \%$ of the total $\mathrm{CH}_{4}$ emissions from anthropogenic activities. The US Environmental Protection Agency (USEPA), Inventory of U.S. Greenhouse Gas Emissions, and Sinks identified manure management as generating 24 and $5 \%$ of $\mathrm{CH}_{4}$ and $\mathrm{N}_{2} \mathrm{O}$ emissions, respectively, from agricultural sources [2-3]. The USEPA has begun to consider regulating GHGs emitted by 
the stationary sources, including manure management from CLOs. Thus, it is essential to obtain accurate estimates of GHG emissions from various ground level area sources (barns/housings, lagoons, pens, settling basins, silage piles, pasturelands, etc.) within CLOs to improve emissions inventories and to devise source-specific abatement strategies. In this chapter, GHG emission sources, emissions process, measurement methods and gas sampling protocol, and migration strategies including air scrubbing technology, biofilters, and best manure management practices in the context of livestock waste management were reviewed and discussed.

\subsection{Sources of GHG in CLOs}

Main sources of pollutant gases are broadly classified as natural (geogenic and biogenic) and anthropogenic. The anthropogenic sources again can be divided into mobile (vehicle, ships, trains, etc.) and stationary (power plants, chemical industries, refineries, intensive land uses, confined animal operations, etc.). Biogenic sources of GHGs, such as those contained in grass, hay, silage, and grains are a major part of bovine diets and are emitted from these biogenic sources during fermentation of starches, lipids, and proteins in the digestive system of cattle (enteric fermentation) and later in the feces and urine. Tables 1 and 2 describe the salient features of the characteristics of manure voided by the animal at CLOs. Ruminant livestock is the principal source of enteric methane emissions to the atmosphere, while manure management such as manure storage and treatment are the most important sources of $\mathrm{CH}_{4}$ and $\mathrm{N}_{2} \mathrm{O}$ emissions [4]. Globally, $\mathrm{CH}_{4}$ is contributing $22 \%$, and $\mathrm{N}_{2} \mathrm{O}$ is contributing $6 \%$ of the total GHG. Enteric $\mathrm{CH}_{4}$ is produced as a waste product of this fermentation process in the rumen. Figure 1 describes the number of factors affecting $\mathrm{CH}_{4}$ production from rumen.

GHG emissions from livestock vary by animal type and growth stage due to different diets, feed conversion mechanisms, and the manure management [5]. Methane is produced by the microbes in the stomach of ruminants due to enteric fermentation, from freshly deposited manure due to bacterial degradation of organic matter, and from storage lagoons and settling basins due to anaerobic degradation of volatile solids by bacteria. Methane, with a global warming potential (GWP) of 21, can affect climate directly through its interaction with long-wave infrared energy and indirectly through atmospheric oxidation reactions. Methane is second in rank to $\mathrm{CO}_{2}$ in importance and contributes around $18 \%$ of the overall greenhouse effect [6]. Table 3 describes the salient features of the three major GHGs. In addition to the anaerobic degradation of the organic materials, $\mathrm{CO}_{2}$ is released from the use of fertilizers in crop/pasture production, fossil fuel used to run farm machinery (tractors, loaders, and irrigation pumps) and feed processing operations, the loss of tree for crop production on land adjacent to CLOs, and carbon loss from the soil for feed production.

Nitrous oxide is a GHG that contributes to stratospheric ozone depletion and is 310 times more potent as a GHG than $\mathrm{CO}_{2}$. Nitrous oxide emissions are associated with manure management and the application and deposition of manure in crop/ pasture land. Indirect $\mathrm{N}_{2} \mathrm{O}$ emissions from livestock production include emissions from fertilizer use for feed 
production, emissions from leguminous feed-crops, and emissions from aquatic sources following fertilizer application. Nitrous oxide is produced in soils through microbial processes of nitrification and denitrification and is released from manure and urine excreta, fertilizer and manure slurry applied for feed-crop production, dry manure piles and aerobic and anaerobic degradation of livestock manure/wastewater in lagoons. The amount of these gaseous emissions from livestock vary by animal type and growth stage due to different diets, daily feed intake, and quality of diet feed conversion mechanism, while GHG emissions from storage and treatment of manure depend on the type of storage, duration of storage, ambient temperature, and manure management practices.

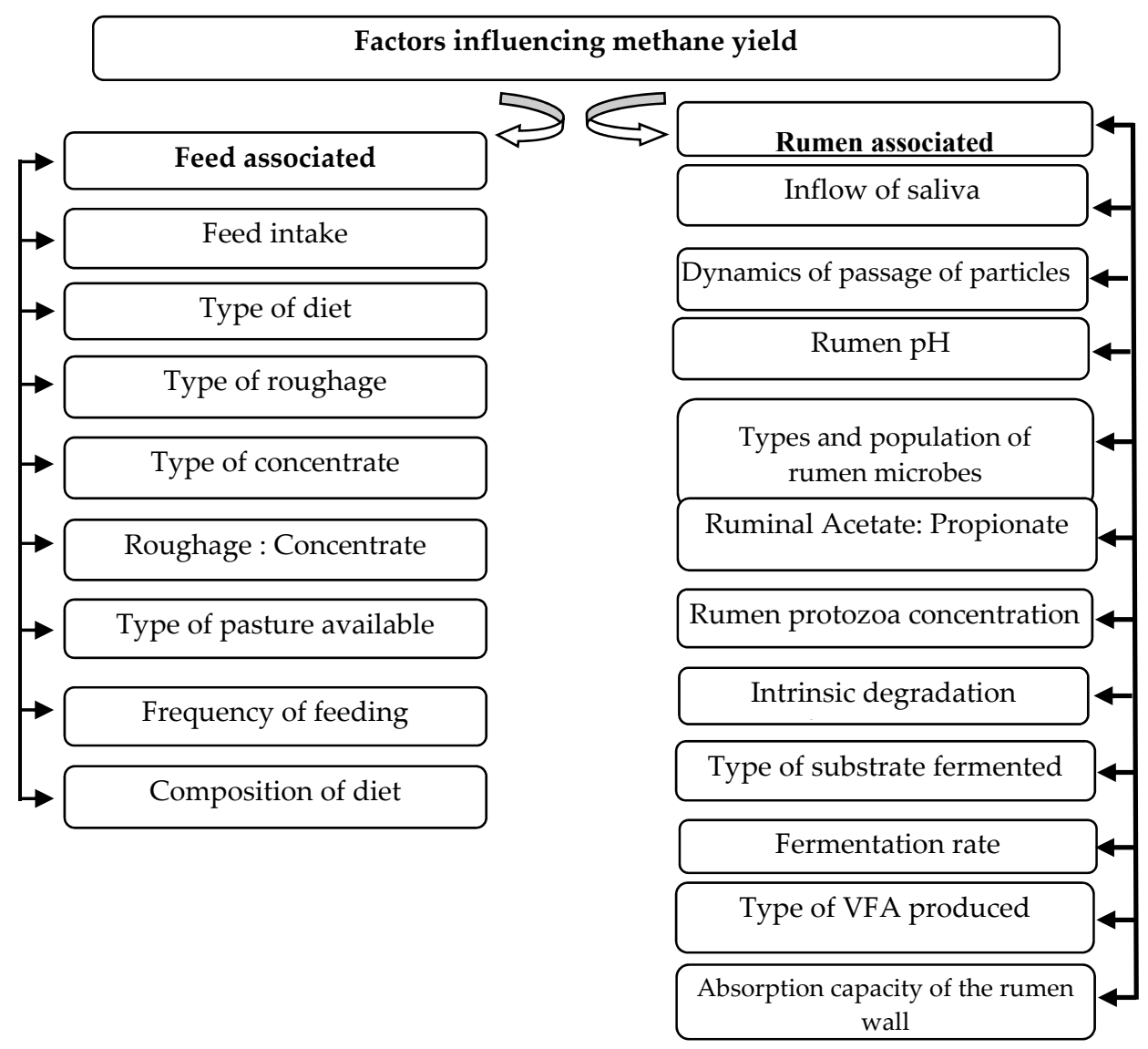

Figure 1. Factors affecting methane production [7]. 


\begin{tabular}{|l|l|l|l|l|l|l|l|l|l|l|l|}
\hline $\begin{array}{l}\text { Animal } \\
\text { Type }\end{array}$ & $\begin{array}{l}\text { Ave- } \\
\text { rage } \\
\text { weight } \\
\text { (pound) }\end{array}$ & $\begin{array}{l}\text { Days } \\
\text { on } \\
\text { feed }\end{array}$ & $\begin{array}{l}\text { Total } \\
\text { solids } \\
\text { (TS) }\end{array}$ & $\begin{array}{l}\text { Volatile } \\
\text { solids } \\
\text { (VS) }\end{array}$ & $\mathrm{N}$ & $\mathrm{P}$ & $\mathrm{P}_{2} \mathrm{O}_{5}$ & $\mathrm{~K}$ & $\mathrm{~K}_{2} \mathrm{O}$ & $\begin{array}{l}\text { Manur } \\
\text { e }\end{array}$ & $\begin{array}{l}\text { Moistu } \\
\text { re }\end{array}$ \\
\hline
\end{tabular}

\section{Cattle}

\begin{tabular}{|c|c|c|c|c|c|c|c|c|c|c|c|}
\hline $\begin{array}{l}\text { Cows/ } \\
\text { Heifers ** }\end{array}$ & 1000 & 365 & 9.5 & 8.1 & 0.36 & 0.048 & 0.11 & 0.23 & 0.28 & 82 & 88 \\
\hline Finishing & 1200 & 153 & 5.1 & 4.2 & 0.36 & 0.048 & 0.11 & 0.248 & 0.30 & 64 & 92 \\
\hline Bulls ** & 1100 & 365 & 6.2 & 5.7 & 0.54 & 0.092 & 0.21 & 0.267 & 0.32 & 80 & 92 \\
\hline Calves** & 450 & 210 & 3.4 & 2.9 & 0.14 & 0.044 & 0.10 & 0.092 & 0.11 & 26 & 92 \\
\hline $\begin{array}{l}\text { Dairy-Milk } \\
\text { cows }^{1}\end{array}$ & 1300 & 365 & 18 & 15.3 & 0.92 & 0.16 & 0.36 & 0.44 & 0.53 & 141 & 87 \\
\hline
\end{tabular}

\section{Swine}

\begin{tabular}{|l|l|l|l|l|l|l|l|l|l|l|l|}
\hline Nursery & 27.5 & 36 & 0.3 & 0.2 & 0.025 & 0.0042 & 0.01 & 0.01 & 0.01 & 2.4 & 90 \\
\hline Finishing & 154 & 120 & 1.0 & 0.8 & 0.083 & 0.0142 & 0.03 & 0.037 & 0.04 & 10 & 90 \\
\hline Gestating & 440 & 365 & 1.1 & 1.0 & 0.071 & 0.02 & 0.05 & 0.048 & 0.06 & 11 & 90 \\
\hline Lactating & 423 & 365 & 2.5 & 2.3 & 0.19 & 0.055 & 0.13 & 0.12 & 0.14 & 25 & 90 \\
\hline Sheep $^{* *}$ & 100 & 365 & 1.1 & 0.9 & 0.04 & 0.009 & 0.02 & 0.03 & 0.04 & 4 & 75 \\
\hline
\end{tabular}

\section{Poultry}

\begin{tabular}{|l|l|l|l|l|l|l|l|l|l|l|l|}
\hline Layers & 3 & 365 & 0.05 & 0.04 & 0.0035 & 0.0011 & 0.003 & 0.0013 & 0.002 & 0.19 & 75 \\
\hline Broilers & 2.8 & 48 & 0.06 & 0.04 & 0.0025 & 0.00073 & 0.002 & 0.0014 & 0.002 & 0.23 & 74 \\
\hline Turkeys $^{2}$ & 25 & 140 & 0.12 & 0.1 & 0.0072 & 0.00212 & 0.005 & 0.0033 & 0.004 & 0.47 & 74 \\
\hline Litter $^{3}$ & & & 2 & 1.6 & 0.089 & 0.038 & 0.086 & 0.049 & 0.059 & 2.5 & 21 \\
\hline Horse $^{4}$ & 1100 & 365 & 8.5 & 6.7 & 0.27 & 0.05 & 0.12 & 0.14 & 0.16 & 56.5 & 85 \\
\hline
\end{tabular}

*ASAE standard D384.2 2005. Manure Production and Characteristics. ASABE, St. Joseph, MI 49085-9659

**Manure Characteristics. 2000. Mid West Plan Service, Ames, IA 50011-3080.MWPS-18,Section I.

${ }^{n}$ Milk vow data on TS,N,P,K and manure provided by Dr. Tamilee Nenich, TCE Dairy Specialist. Volatile solids (VS) estimated to be $85 \%$ of TS.

$1 \%, \mathrm{wb}=$ percent $\mathrm{wt}$ basis.

2Days on feed data from "economic Impact of the Texas Poultry Industry," 2004, TCE publication, L-5214.Average weight, TS,VS,N,P,K and total manure averaged from data for female and male turkeys.

3Poultry Waste Management Handbook," 1999. Natural Resource, Agriculture, and Engineering Service. Ithaca, NY 14853-5701. NARES-132. Pounds of whole poultry litter (as removed from production houses) per broiler sold. N,P and $\mathrm{K}$ values in pounds per 2.5 pounds of litter.

${ }^{4}$ Average weight, TS,VS,N,P,K and total manure averaged from data for sedentary and intense exercise horses.

Table 1. Animal manure production and characteristics [8].* 


\begin{tabular}{|c|c|c|c|c|c|c|c|c|c|c|c|}
\hline Animal type & Year* & $\begin{array}{l}\text { Animal } \\
\text { numbers** } \\
\text { (thousands) }\end{array}$ & $\begin{array}{l}\text { Total } \\
\text { manure }\end{array}$ & TS & VS & $\mathrm{N}$ & $\mathrm{P}$ & $\mathrm{P}_{2} \mathrm{O}_{5}$ & K & $\mathrm{K}_{2} \mathrm{O}$ & $\begin{array}{l}\text { Total } \\
\text { energy }^{* * *}\end{array}$ \\
\hline & & & \multicolumn{8}{|c|}{$\begin{array}{c}\text { Thousands of tons per year on an as excreted" } \\
\text { basis }\end{array}$} & $\begin{array}{l}\text { BTU } \times 10^{12} \\
\text { Tera BTUs }\end{array}$ \\
\hline \multicolumn{12}{|l|}{ Cattle } \\
\hline Cows/Heifers & \multirow{5}{*}{2006} & 5780 & 86498 & 10021 & 8544 & 380 & 51 & 116 & 243 & 291 & 145 \\
\hline Finishing & & 5520 & 27026 & 2149 & 1764 & 152 & 20 & 46 & 105 & 126 & 30 \\
\hline Bulls & & 370 & 5402 & 419 & 385 & 36 & 6 & 14 & 18 & 22 & 6.43 \\
\hline Calves & & 2430 & 6634 & 868 & 740 & 36 & 11 & 26 & 23 & 28 & 12.6 \\
\hline Milk Cows & & 334 & 8581 & 1096 & 936 & 56 & 9.7 & 22.3 & 32 & 32 & 15.8 \\
\hline \multicolumn{12}{|l|}{ Swine } \\
\hline Nursery & \multirow{3}{*}{2006} & 270 & 12 & 1.36 & 1.16 & 0.12 & 0.02 & 0.05 & 0.05 & 0.06 & 0.02 \\
\hline Finishing & & 565 & 339 & 34 & 28 & 2.81 & 0.48 & 1.10 & 1.24 & 1.49 & 0.48 \\
\hline Other $^{1}$ & & 95 & 312 & 31 & 29 & 2.26 & 0.65 & 1.49 & 1.46 & 1.75 & 0.48 \\
\hline $\begin{array}{l}\text { Sleep \& } \\
\text { Goats }^{2-}\end{array}$ & 2006 & 2140 & 1759 & 484 & 400 & 18 & 4 & 9 & 13 & 16 & 6.8 \\
\hline \multicolumn{12}{|l|}{\begin{tabular}{|l|} 
Poultry \\
\end{tabular}} \\
\hline Layers $^{3}$ & 2005 & 18688 & 648 & 167 & 123 & 12 & 4 & 9 & 4 & 5 & 2.1 \\
\hline Broilers & 2005 & 627900 & 3451 & 874 & 659 & 38 & 11 & 25 & 21 & 26 & 11.2 \\
\hline Turkeys $^{4}$ & 2004 & 14100 & 468 & 120 & 96 & 7 & 2 & 5 & 3 & 4 & 1.63 \\
\hline Litter & & & 785 & 622 & 494 & 28 & 12 & 27 & 15.4 & 18 & 8.4 \\
\hline Horses $^{5}$ & 1998 & 1067 & 11000 & 1655 & 1304 & 53 & 10 & 23 & 26 & 32 & 22.2 \\
\hline
\end{tabular}

*Year of estimated total population or production data from National Agricultural Statistical Services

** Animals finished or on feed per year.

*** Dry and ash free basis

${ }^{1}$ Includes all hogs other than nursery and grow-finish. Estimates based on average nutrient data from gestating lactating sows in Table I.

${ }^{2}$ Includes sheep and goats. Manure and nutrient totals calculated using sheep data only.

${ }^{3}$ Include hens and pullets of egg-laying age.

${ }^{4}$ animal numbers for turkey estimated from difference between total turkey and broiler population in Texas (615.6

million from TCE publication L-5214) and National Agricultural Statistical Service estimated number of broilers (601.5 million in 2004).

${ }^{5}$ Animal numbers for horses adopted form Texas Horse Industry Report, 1998, and from the Texas Horse Industry Quality Audit initiative, TCE, January 1998.

Table 2. Animal manure production and characteristics [8].*

\begin{tabular}{|c|c|c|c|c|c|}
\hline GHG & $\begin{array}{l}\text { MW } \\
\left(\mathrm{g} \mathrm{mol}^{-1}\right)\end{array}$ & $\begin{array}{l}\text { Typical ambient } \\
\text { concentration } \\
(\text { ppm) }\end{array}$ & $\begin{array}{l}\text { Life time } \\
(\mathrm{Yr})\end{array}$ & 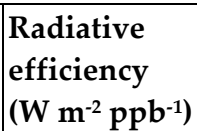 & $\begin{array}{l}\text { Global } \\
\text { Worming } \\
\text { Potential }\end{array}$ \\
\hline $\mathrm{CO}_{2}$ & 44.01 & 380 & Up to 100 & $1.4 \times 10^{-5}$ & 1 \\
\hline $\mathrm{CH}_{4}$ & 16.04 & 1.7 & 12 & $3.7 \times 10^{-4}$ & 21 \\
\hline $\mathrm{N}_{2} \mathrm{O}$ & 44.01 & 320 & 114 & $3.03 \times 10^{-3}$ & 310 \\
\hline
\end{tabular}

Table 3. Global warming potential of the GHGs [1] 


\subsection{Greenhouse gas inventory}

The livestock industry is a significant contributor to the economy of any country. More than one billion ton of manure is produced annually by livestock in the United States. Animal manure is a valuable source of nutrients and renewable energy. However, most of the manure is collected in storage/treatment structures or left to decompose in the open, which poses a significant environmental hazard. Tables $4 a, 4 b$, and $4 c$ summarized the studies on GHG emission rates (ERs) from dairy, feed yard and swine operations. Based on a literature review using limited data for free-stall and naturally ventilated dairy operations, emissions of $\mathrm{CO}_{2}$ from the dairy slurry manure storage facilities averaged $72 \mathrm{~kg} \mathrm{CO}_{2} \mathrm{~m}^{-3} \mathrm{yr}^{-1}$ (data ranged from 8.6 to $117 \mathrm{~kg} \mathrm{CO}_{2} \mathrm{~m}^{-3} \mathrm{yr}^{-1}$ ) [9-11]. Emissions of $\mathrm{CO}_{2}$ from dairy housing averaged 1,989 $\mathrm{kg} \mathrm{CO}_{2} \mathrm{hd}^{-1} \mathrm{yr}^{-1}$ (data ranged from 1,697 to 2,281 $\mathrm{kg} \mathrm{CO}_{2} \mathrm{hd}^{-1} \mathrm{yr}^{-1}$, where hd is per head) [11]. Kinsman et al. [12] reported that the mean daily $\mathrm{CH}_{4}$ emission per dairy cow (602 kg mean bodyweight) in a tie-stall barn ranged from 373 to $617 \mathrm{~g} \mathrm{CH}_{4} \mathrm{AU}^{-1} \mathrm{~d}^{-1}(436$ to $721 \mathrm{~L}$ ), while the mean daily $\mathrm{CO}_{2}$ emission per cow ranged from11,900 to $17,500 \mathrm{~g} \mathrm{CO}_{2} \mathrm{AU}^{-}$ ${ }^{1} \mathrm{~d}^{-1}(5,032$ to $7,427 \mathrm{~L})$. In a study by Amon et al. [13], $\mathrm{CH}_{4}$ and $\mathrm{N}_{2} \mathrm{O}$ emissions per livestock unit (LU=600 kg of body weight) or animal unit ( $\mathrm{AU}=500 \mathrm{~kg}$ of body weight) from tie stalls for dairy cows were measured several times in the course of a year. Average emissions were $619.2 \mathrm{mg} \mathrm{N}_{2} \mathrm{O} \mathrm{LU}^{-1} \mathrm{~d}^{-1}\left(516 \mathrm{mg} \mathrm{N}_{2} \mathrm{O} \mathrm{AU} \mathrm{Ad}^{-1}\right)$, and $194.4 \mathrm{~g} \mathrm{CH}_{4} \mathrm{LU}^{-1} \mathrm{~d}^{-1}\left(162 \mathrm{~g} \mathrm{CH}_{4} \mathrm{AU}^{-1} \mathrm{~d}^{-1}\right)$. Emissions of $\mathrm{CH}_{4}$ and $\mathrm{N}_{2} \mathrm{O}$ from animal housing averaged 54 (1.0-100) $\mathrm{kg} \mathrm{CH}_{4} \mathrm{hd}^{-1} \mathrm{yr}^{-1}$ and 0.3 (0.0-0.6) $\mathrm{kg} \mathrm{N}_{2} \mathrm{O} \mathrm{hd}^{-1} \mathrm{yr}^{-1}$, respectively [11,13]. Ngwabie et al. [14] reported $\mathrm{CH}_{4}$ emissions ranging from 25 to $312 \mathrm{~g} \mathrm{hd}^{-1} \mathrm{~d}^{-1}$ (9 to $114 \mathrm{~kg} \mathrm{hd}^{-1} \mathrm{yr}^{-1}$ ) in a naturally ventilated dairy barn. Methane emission estimates for dairy cows have been reported to range from $230 \mathrm{~g} / \mathrm{cow} /$ day [15] to $323 \mathrm{~g} \mathrm{cow}^{-1} \mathrm{~d}^{-1}$ [16]. Fiedler and Muller [17] show that $\mathrm{CH} 4$ emissions from naturally ventilated dairy barns ranged from 672 to $528 \mathrm{~g} \mathrm{cow}^{-1} \mathrm{~d}^{-1}$. A study conducted in California, USA, indicated that $\mathrm{CH}_{4}$ emissions of 296 and $438 \mathrm{~g} \mathrm{cow}^{-1} \mathrm{~d}^{-1}$ for dry and lactating cows, respectively, were mainly due to enteric fermentation and fresh manure produced negligible amount of $\mathrm{CH}_{4}$ [18]. Most dairy facilities are naturally ventilated and do not have controlled air exchange. Therefore, in addition to the large variations in methane emission rates causing a range of methane concentrations in dairy facilities, $\mathrm{CH}_{4}$ concentrations in dairy barns will also vary with geographical locations, weather conditions, and ventilation management practices. Only limited studies have been conducted on indoor air methane concentrations in dairy barns.

Most of the published literature reporting $\mathrm{CH}_{4}$ emissions from feedlot manure systems used atmospheric dispersion modeling (inverse dispersion, backward Lagrangian stochastic model, IPCC tiers I and II algorithm, and Blaxter and Clapperton algorithm) to estimate emissions from a whole farm [19-21]. Zoe et al. [19] estimated summer $\mathrm{CH}_{4}$ ER data for two Australian feedyards using an open-path tunable near infrared diode laser coupled with backward Lagrangian stochastic model of atmospheric dispersion. Methane ERs reported were 146 and $166 \mathrm{~g} \mathrm{hd}^{-1} \mathrm{~d}^{-1}$ for Victoria and Queensland, respectively. Using the same techniques, the average $\mathrm{CH}_{4}$ emissions were 166 and $214 \mathrm{~g} \mathrm{CH}_{4} \mathrm{hd}^{-1} \mathrm{~d}^{-1}$ for feedlots in Queensland and Alberta, respectively [20]. Average daily $\mathrm{CH}_{4}$ emissions were estimated to be $323 \mathrm{~g} \mathrm{hd}^{-1} \mathrm{~d}^{-1}$ for a large beef feedlot in western Canada using the inverse dispersion 
model [21]. Phetteplace et al. [22] determined GHG emissions from simulated beef and dairy livestock systems in the United States using a computer spreadsheet program. The methane $\mathrm{N}_{2} \mathrm{O}$ and $\mathrm{CO}_{2}$ ERs reported were 1.56, 11.4 and $3411 \mathrm{~g} \mathrm{hd}^{-1} \mathrm{~d}^{-1}$ from manure management systems of a feedlot. Direct measurements using micrometeorological mass difference technique reported $70 \mathrm{~g} \mathrm{CH}_{4} \mathrm{hd}^{-1} \mathrm{~d}^{-1}$ emissions from a confined beef feedyard in Australia where animals were fed a highly digestible high grain diet [23].

Emission rates of $\mathrm{CO}_{2}, \mathrm{CH}_{4}$ and $\mathrm{N}_{2} \mathrm{O}$ from different pig housing systems are presented in Table 4c. $\mathrm{CH}_{4}$ was observed to be emitted from all swine housing systems showing a large variation because of the different animal types, housing systems, and manure handling methods [24-27]. Methane emissions from fattening pigs range between 0.5 to $135 \mathrm{~g} \mathrm{pig}^{-1} \mathrm{~d}^{-1}$, whereas emissions of 0.77 and $5.8 \mathrm{~g} \mathrm{pig}^{-1} \mathrm{~d}^{-1}$ (Table 4c) were reported for sows and weaners, respectively. Similarly, $\mathrm{CO}_{2}, \mathrm{CH}_{4}$, and $\mathrm{N}_{2} \mathrm{O}$ ERs in gestation pigs in North Dakota (USA) ranged from 5,350-15,830, 116-572, and 0.06-7.3 $\mathrm{g} \mathrm{d}^{-1} \mathrm{pig}^{-1}$., respectively [28]. Similarly, $\mathrm{CO}_{2}$ ERs for different growing stages from swine operation ranged from 5,920 to 30,000 g $\mathrm{pig}^{-1} \mathrm{~d}^{-}$ 1. The highest $\mathrm{N}_{2} \mathrm{O}$ ER was estimated from swine nursery in China [29]. Animal feces temporarily stored indoors deep pits are the principal source of $\mathrm{CH}_{4}$ emissions in swine housings. The quantity of $\mathrm{CH}_{4}$ emitted by the animal itself and the amount emitted from barns of fattening pigs is influenced by the diet and digestibility, daily weight gain of the pigs, and the temperature and type of housing system. Methane emissions are lower in summer when compared with autumn and winter due to higher air exchange rates. Also, the $\mathrm{CH}_{4}$ generation might be influenced by the availability of oxygen over the emitting surfaces [30]. Significant amount $\mathrm{N}_{2} \mathrm{O}$ emits from pig manure handling system is exclusively originated from deep litter and compost systems. The variation in the $\mathrm{N}_{2} \mathrm{O}$ emissions mainly depends on the kind of housing system. Fattening pigs raised on partly or fully slatted floor emit very little $\mathrm{N}_{2} \mathrm{O}$ while higher emissions reported for fatteners in deep litter and compost systems [30].

\begin{tabular}{|c|c|c|c|c|c|c|c|}
\hline $\begin{array}{l}\text { Facility type and } \\
\text { ground sources }\end{array}$ & \begin{tabular}{|l|} 
Animal \\
Number
\end{tabular} & $\begin{array}{l}\mathrm{CH}_{4} \\
\mathrm{~g} / \mathrm{LU} / \mathrm{d}\end{array}$ & \begin{tabular}{|l}
$\mathrm{CO}_{2}$ \\
$\mathrm{~kg} / \mathrm{LU} / \mathrm{d}$
\end{tabular} & $\begin{array}{l}\mathrm{N}_{2} \mathrm{O} \\
\mathrm{g} / \mathrm{LU} / \mathrm{d}\end{array}$ & Technology used & Remarks & References \\
\hline $\begin{array}{l}\text { Free-stall dairy: } \\
\text { Barn, settling } \\
\text { basins, loafing } \\
\text { pen, primary } \\
\text { and secondary } \\
\text { lagoon, } \\
\text { walkway, silage } \\
\text { pile. }\end{array}$ & 500 & 181 & 6.6 & 6 & $\begin{array}{l}\text { Dynamic flux } \\
\text { chamber coupled } \\
\text { with GC and } \\
\text { chromatograms } \\
\text { acquired directly } \\
\text { at the field }\end{array}$ & $\begin{array}{l}\text { Five consecutive } \\
\text { days in summer } \\
\text { and winter; } \\
\text { Reported values } \\
\text { are annualized }\end{array}$ & [31] \\
\hline $\begin{array}{l}\text { Free-stall dairy: } \\
\text { Barn, settling } \\
\text { basins, loafing } \\
\text { pen, primary } \\
\text { and secondary } \\
\text { lagoon, open-lot, } \\
\text { compost piles. }\end{array}$ & 3500 & 836 & 5.5 & 3.4 & $\begin{array}{l}\text { Dynamic flux } \\
\text { chamber coupled } \\
\text { with GC and } \\
\text { chromatograms } \\
\text { acquired directly } \\
\text { at the field }\end{array}$ & $\begin{array}{l}\text { Five consecutive } \\
\text { days in summer }\end{array}$ & [32] \\
\hline $\begin{array}{l}\text { Open-lot dairy: } \\
\text { Open-lot pen, }\end{array}$ & 700 & 0.20 to & & & OP-PATH FTIR & One to two days & [33] \\
\hline
\end{tabular}




\begin{tabular}{|c|c|c|c|c|c|c|c|}
\hline $\begin{array}{l}\text { storage lagoon, } \\
\text { and composting } \\
\text { areas. } \\
\end{array}$ & & 0.55 & & & \begin{tabular}{|l} 
(MDA Atlanta) \\
/BLS (Wind-Trax \\
2.0) \\
\end{tabular} & \begin{tabular}{|l|} 
in January, \\
March and June, \\
and September. \\
\end{tabular} & \\
\hline $\begin{array}{l}\text { Tied-stall dairy: } \\
\text { Housing, } \\
\text { Storage, and } \\
\text { spreading }\end{array}$ & 12 cows & 194.4 & & 0.619 & $\begin{array}{l}\text { Mobile dynamic } \\
\text { chamber coupled } \\
\text { with FTIR and } \\
\text { GC. Sampled } \\
\text { alternately } \\
\text { incoming- } \\
\text { outgoing air of } \\
\text { the chamber. }\end{array}$ & $\begin{array}{l}\text { Several times in } \\
\text { course of a year, } \\
\text { and } 24 \text { hours a } \\
\text { day during each } \\
\text { experiment. } \\
\mathrm{LU}=600 \mathrm{~kg} \text { and } \\
\mathrm{AU}=500 \mathrm{~kg}\end{array}$ & [13] \\
\hline $\begin{array}{l}\text { Tied-stall dairy: } \\
\text { Housing } \\
\text { (enteric), } \\
\text { Manure storage, }\end{array}$ & 118 & $\begin{array}{l}373 \\
24\end{array}$ & $14-20$ & & $\begin{array}{l}\text { DTs: } \\
0-5000 \text { ppm for } \\
\mathrm{CO}_{2} \text { and } 0-1000 \\
\text { ppm for } \mathrm{CH}_{4} .\end{array}$ & $\begin{array}{l}112 \text { days } \\
\text { BW } 602 \pm 62\end{array}$ & {$[12]$} \\
\hline $\begin{array}{l}\text { Naturally } \\
\text { ventilated dairy } \\
\text { building with } \\
\text { daily manure } \\
\text { collection } \\
\end{array}$ & 720 & 305 & 8.9 & NR & \begin{tabular}{|l|} 
Ventilation by \\
$\mathrm{CO}_{2}$ balance and \\
concentrations \\
measured by \\
INNOVA 1312 \\
\end{tabular} & $\begin{array}{l}5 \text { consecutive } \\
\text { days in spring, } \\
\text { summer, } \\
\text { autumn, and } \\
\text { winter } \\
\end{array}$ & {$[34]$} \\
\hline $\begin{array}{l}\text { Free-stall dairy: } \\
\text { Dry cows } \\
\text { (Holstein) } \\
\text { Lactating cows }\end{array}$ & $\begin{array}{l}9 \\
9\end{array}$ & $\begin{array}{l}296 \\
438\end{array}$ & $\begin{array}{l}\mathrm{NR} \\
\mathrm{NR}\end{array}$ & $\begin{array}{l}\text { ND } \\
\text { ND }\end{array}$ & $\begin{array}{l}\text { PAS Multi-gas } \\
\text { Monitor } \\
\text { (INNOVA 1412) }\end{array}$ & $\begin{array}{l}\text { Manure and } \\
\text { Enteric } \mathrm{CH}_{4} \text { in } \\
\text { environmental } \\
\text { chambers. BWs } \\
770 \text { and } 565 \mathrm{~kg} \\
\end{array}$ & [18] \\
\hline $\begin{array}{l}\text { Open-lot Dairy: } \\
\text { Total emissions } \\
\text { rates from open- } \\
\text { lot, runoff pond, } \\
\text { and compost } \\
\text { area }\end{array}$ & 10,000 & 1390 & NR & 20 & $\begin{array}{l}\text { INNOVA } 1412 \\
\text { OP-FTIR coupled } \\
\text { with BLS Wind- } \\
\text { Trax2.0 }\end{array}$ & \begin{tabular}{|l|} 
Four months \\
(January, March, \\
June, September) \\
and 2-3 days in \\
each month
\end{tabular} & {$[35]$} \\
\hline $\begin{array}{l}\text { Free-stall dairy: } \\
\text { Open lot } \\
\text { Run-off pond } \\
\text { Compost area }\end{array}$ & 10,800 & $\begin{array}{l}490 \\
952 \\
125\end{array}$ & $\begin{array}{l}28 \\
6 \\
12\end{array}$ & $\begin{array}{l}10 \\
4.5 \\
8.3\end{array}$ & \begin{tabular}{|l|} 
PAS Multi-gas \\
Monitor \\
(INNOVA 1412) \\
coupled with BLS \\
(Wind-trax 2.0) \\
\end{tabular} & $\begin{array}{l}2 \text { or } 3 \text { days in } \\
\text { each month over } \\
\text { a year; } \\
\text { BW } 635 \mathrm{~kg}\end{array}$ & {$[36]$} \\
\hline $\begin{array}{l}\text { Dairy with } \\
\text { Conventional } \\
\text { bedding } \\
\text { Straw bedding } \\
\end{array}$ & & $\begin{array}{l}700 \pm \\
400 \\
1400 \pm \\
200 \\
\end{array}$ & & & $\begin{array}{l}\text { TDLAS (DT: } 100 \\
\text { ppb) coupled } \\
\text { with Gaussian } \\
\text { plume model }\end{array}$ & $\begin{array}{l}7 \text { conventional } \\
\text { farms } \\
3 \text { straw farms }\end{array}$ & {$[37]$} \\
\hline \multicolumn{8}{|c|}{$\mathrm{ND}=$ not detected by sensor; $\mathrm{NR}=$ not reported } \\
\hline \multicolumn{8}{|c|}{ a. } \\
\hline $\begin{array}{l}\text { Facility type } \\
\text { and ground } \\
\text { sources }\end{array}$ & \begin{tabular}{|l|} 
Animal \\
Number
\end{tabular} & $\mathrm{CH}_{4}$ & $\mathrm{CO}_{2}$ & $\mathrm{~N}_{2} \mathrm{O}$ & Technology used & Remarks & References \\
\hline \begin{tabular}{|l|} 
Feedyard: \\
Feedlot
\end{tabular} & 16,995 & 323 & & & $\begin{array}{l}\text { OP-TDLAS/ BLS } \\
\text { (Wind-Trax 2.0) }\end{array}$ & $\begin{array}{l}12 \text { days, High } \\
\text { grain diets and }\end{array}$ & [21] \\
\hline
\end{tabular}




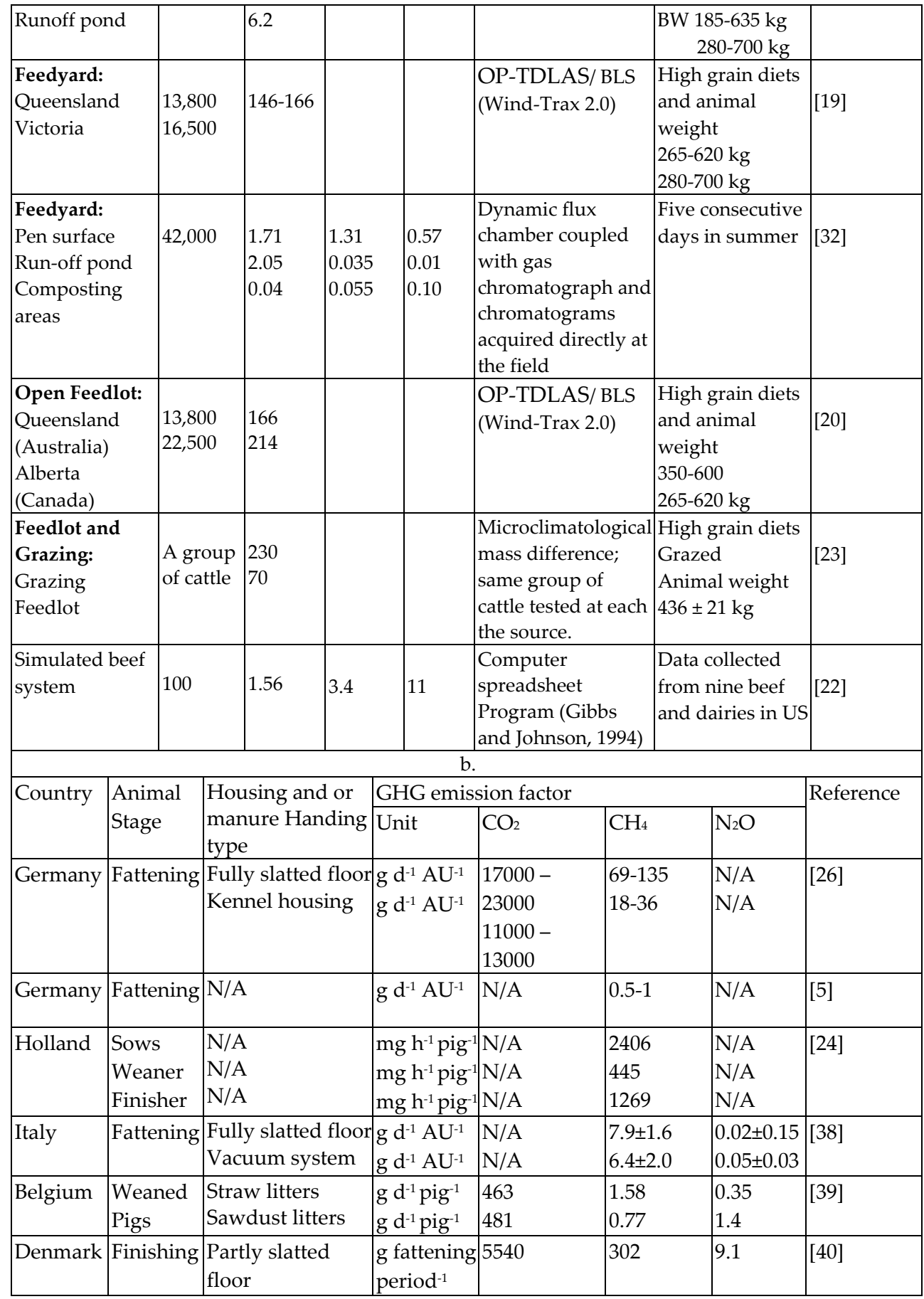




\begin{tabular}{|c|c|c|c|c|c|c|c|}
\hline USA & \begin{tabular}{|l|} 
Farrow- \\
to-finish \\
Farrow- \\
to- \\
weaner
\end{tabular} & $\begin{array}{l}\text { N/A } \\
\text { N/A }\end{array}$ & $\begin{array}{l}\mathrm{g} \mathrm{d}^{-1} \text { pig }^{-1} \\
\mathrm{~g} \mathrm{~d}^{-1} \text { pig }^{-1}\end{array}$ & $\begin{array}{l}\text { N/A } \\
\text { N/A }\end{array}$ & $\begin{array}{l}6.9-29.2 \\
46.2\end{array}$ & $\begin{array}{l}\mathrm{N} / \mathrm{A} \\
\mathrm{N} / \mathrm{A}\end{array}$ & [27] \\
\hline USA & Gestation & $\begin{array}{l}\text { Deep pit }(3 \mathrm{~m}) \\
\text { manure storage } \\
\text { emptied twice a } \\
\text { year }\end{array}$ & $\mathrm{g} \mathrm{d}^{-1} \mathrm{AU}^{-1}$ & $5350-15830$ & $116-572$ & $0.06-7.3$ & [28] \\
\hline \begin{tabular}{|l|} 
United \\
Kingdom \\
\end{tabular} & Fattening & Slurry & $\mathrm{g} \mathrm{d}^{-1} \mathrm{AU}^{-1}$ & N/A & 85 & 0.4 & [41] \\
\hline China & $\begin{array}{l}\text { Fattening } \\
\text { Nursery } \\
\text { Gestation } \\
\text { Farrowing }\end{array}$ & $\begin{array}{l}\text { Manure scrapped } \\
\text { twice a day } \\
\text { Flushed twice a } \\
\text { day } \\
\text { Manure removed } \\
\text { twice a day } \\
\text { Removed as } \\
\text { produced }\end{array}$ & 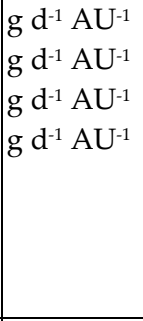 & $\begin{array}{l}16730 \pm 1060 \\
29670 \pm 1090 \\
5920 \pm 440 \\
7490 \pm 110\end{array}$ & \begin{tabular}{|l}
$32.1 \pm 11.7$ \\
$58.4 \pm 21.8$ \\
$9.6 \pm 1.9$ \\
$9.6 \pm 3.6$
\end{tabular} & $\begin{array}{l}0.86 \pm 0.75 \\
1.29 \pm 0.37 \\
0.75 \pm 0.56 \\
0.54 \pm 0.15\end{array}$ & [29] \\
\hline Taiwan & NA & $\begin{array}{l}3 \text { stages (solid } \\
\text { separation, } \\
\text { anaerobic and } \\
\text { aerobic } \\
\text { treatment) plug- } \\
\text { flow type } \\
\text { wastewater } \\
\text { treatment plant. }\end{array}$ & g hd-1 d-1 & 11.5 & 13.3 & 0.03 & [42] \\
\hline
\end{tabular}

Table 4. a. Summary of GHG emission rates (ERs) estimated from dairy operations at different ground level area sources (GLAS) as reported by previous researchers (LU = live weight, BW= body weight). b. Summary of GHG emission rates (ERs) estimated from feedyard operations at different ground level area sources (GLAS) as reported by previous researchers. c. Summary of GHG ERs of swine operations with different housing and management schemes as reported in the literature (updated after Dong et al. [29]). AU = animal weight $=500 \mathrm{~kg}$ live weight.

\section{Emission process}

\subsection{Methane emission process}

During anaerobic fermentation, organic wastes are biologically degraded in the absence of oxygen to $\mathrm{CH}_{4}, \mathrm{CO}_{2}, \mathrm{~N}_{2}$, and $\mathrm{H}_{2} \mathrm{~S}$. Methanogenic fermentation of organic materials occurs under strictly anaerobic and low redox potential $(\mathrm{Eh}<-200 \mathrm{mV})$ conditions where sulphate and nitrate concentrations are low [43]. Methanogens produce methane by breaking down organic matter in the absence of oxygen (anaerobically), releasing $\mathrm{CO}_{2}$ and $\mathrm{CH}_{4}$ according to the following equation: 
$\mathrm{C}_{6} \mathrm{H}_{12} \mathrm{O}_{6}$

\section{Microbial}

Action

This transformation requires the successive action of four different types of micro-organisms as shown in Figure 2 that degrade complex molecules to simpler compounds [44]:

a. Hydrolytic microflora: hydrolysis of longer chain carbohydrates, fats and proteins are broken into shorter chain molecules. This can be aerobic, facultative, or strictly anaerobic.

b. Fermentative microflora: acidogenesis of shorter chain molecules produce carbon dioxide, hydrogen sulfide, alcohol, and more volatile fatty acids. This can be facultative or strictly anaerobic.

c. Homoacetogenic or syntrophic microflora: acetogenesis from previous metabolites. Simple molecules created through the first two steps are digested by specific bacteria to produce acetic acids as well as hydrogen and carbon dioxide.

d. Methanogens: methanogenesis of simple compounds such as $\mathrm{H}_{2}+\mathrm{CO}_{2}$ and acetate. Products developed in stages 1-3 and convert $\left(\mathrm{H}_{2}+\mathrm{CO}_{2}\right.$ and acetate) them into methane, carbon dioxide and trace amount of other gases).

Numerous physical, chemical, and biological factors influence the physiology of methanogenic archaea and characteristics manure (organic waste) and the microenvironment of the anaerobic systems. One of the important obvious factors is temperature. Methane production increases with increasing temperature if other parameters are kept constant. The main factor determining the degree of $\mathrm{CH}_{4}$ production is the amount of degradable organic matter contained in the effluent and organic animal waste. This fraction is commonly expressed in terms of biochemical or chemical oxygen demand (BOD or COD). The higher the BOD/COD value, the more $\mathrm{CH}_{4}$ is produced. The potential amount of $\mathrm{CH}_{4}$ formation from animal feces will depend on the amount of fecal matter excreted, the physical form of the deposit (shape, size), excretal form (solid, slurry, and effluent), climatic and soil conditions, and the length of time these deposits remain intact before being decomposed [43].

Methane production from manure when managed in a controlled setting will depend on the type of waste, temperature, and duration of storage, and the manner in which the waste is handled. On the other hand, emissions during composting of dung depend on aeration rate, water content, thermal insulation, weather conditions, and manure composition. Methane production during composting is related to the lack of oxygen in the decomposing biomass. A study reported that anaerobic digestion of the slurry reduced $\mathrm{CH}_{4}$ emissions after field application, because the easily degradable organic compounds were already converted to $\mathrm{CO}_{2}$ and $\mathrm{CH}_{4}$ during digestion in the biogas plant [45]. The factors affecting $\mathrm{CH}_{4}$ emission by soils are summarized as follows [43, 44]:

a. Gas diffusion in relation to oxydo-reduction level and $\mathrm{CH}_{4}$ transfer, in particular the water content, the nature of clays, and the type of vegetation. 
b. Microbial activities in general temperature, $\mathrm{pH}$, Eh, substrate availability, physicochemical properties of soils.

c. Methanogenesis and, in particular, the competition with denitrification and sulphate reduction.

d. Methane-mono-oxygenazse activity - concentrations of $\mathrm{H}_{2}, \mathrm{CH}_{4}, \mathrm{NH}_{4}+, \mathrm{NO}_{3}{ }^{-}, \mathrm{Cu}$.

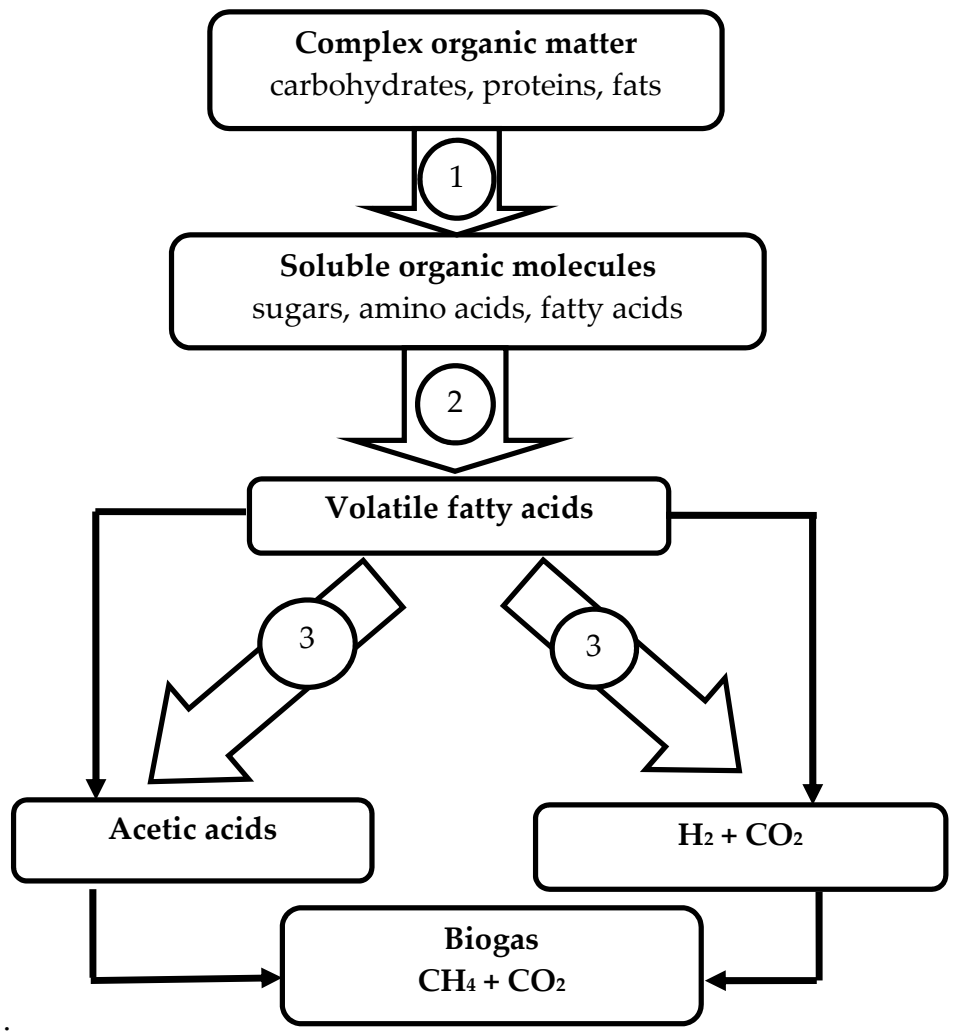

Figure 2. Schematic diagram showing anaerobic fermentation process.

\subsection{Nitrous oxide emission process}

Nitrous oxide $\left(\mathrm{N}_{2} \mathrm{O}\right)$, nitrogen monoxide $(\mathrm{NO})$, and nitrogen dioxide $\left(\mathrm{NO}_{2}\right)$ are the most plentiful nitrogen oxides in the atmosphere and being produced lavishly by biogenic sources such as plants and yeasts. Nitrous oxide is an ozone $\left(\mathrm{O}_{3}\right)$ depleting substance which reacts with $\mathrm{O}_{3}$ in both the troposphere and in the stratosphere and has a long half-life (100 150 years). In livestock agriculture, $\mathrm{N}_{2} \mathrm{O}$ emissions are associated with manure management and the application and deposition of manure in crop/ pasture land. Indirect $\mathrm{N}_{2} \mathrm{O}$ emissions from livestock production include emissions from fertilizer use for feed production, leguminous feed crops, and emissions from aquatic sources following fertilizer application. Thus, fertilized soils are important sources of $\mathrm{N}_{2} \mathrm{O}$. Soils contribute about $65 \%$ of the total 
$\mathrm{N}_{2} \mathrm{O}$ produced by terrestrial ecosystems [46]. Nitrous oxide gas is formed in soils during the microbiological processes of nitrification and denitrification as shown in equations 2 and 3 . Nitrous oxide production by nitrifying bacteria may arise either during $\mathrm{NH}_{4}^{+}$oxidation to $\mathrm{NO}_{2}{ }^{-}$or during dissimilatory $\mathrm{NO}_{2}^{-}$reduction when $\mathrm{O}_{2}$ supply is limited. During denitrification, $\mathrm{N}_{2} \mathrm{O}$ is an intermediate product in the dissimilatory reduction of $\mathrm{NO}_{3}^{-}$and $\mathrm{NO}_{2}{ }^{-}$to $\mathrm{N}_{2}$ under anaerobic conditions and may, therefore, be produced and consumed by denitrifying bacteria in soil [47].

Fertilizer and manure type may affect $\mathrm{N}_{2} \mathrm{O}$ emission in several ways [48] such as: (1) the type of $\mathrm{N}\left(\mathrm{NO}_{3}{ }^{-}, \mathrm{NH}_{4}{ }^{+}\right.$, and organic $\left.\mathrm{N}\right)$ which affects $\mathrm{N}_{2} \mathrm{O}$ production during nitrification and denitrification, (2) the presence of freely available $\mathrm{C}$, which stimulates denitrification activity and $\mathrm{O}_{2}$ consumption in the soil following its application, and (3) effects on biological, chemical and physical soil processes because of changes in $\mathrm{pH}$ and the addition of other compounds (salt, water). The availability of $\mathrm{N}\left(\mathrm{NH}_{4}^{+}\right.$and $\left.\mathrm{NO}_{3}^{-}\right)[43,49,50]$, and the factors that alter the redox potential of the soil, such as changes in soil moisture [51-53], soil texture, and organic $\mathrm{C}$, have major effects on the production of $\mathrm{N}_{2} \mathrm{O}$ in soils. In addition, several soil management practices such as tillage, soil compaction [54-55], irrigation, and drainage affect the production and transport of $\mathrm{N}_{2} \mathrm{O}$ release by influencing the physical condition of the soils such as aeration and soil water content.

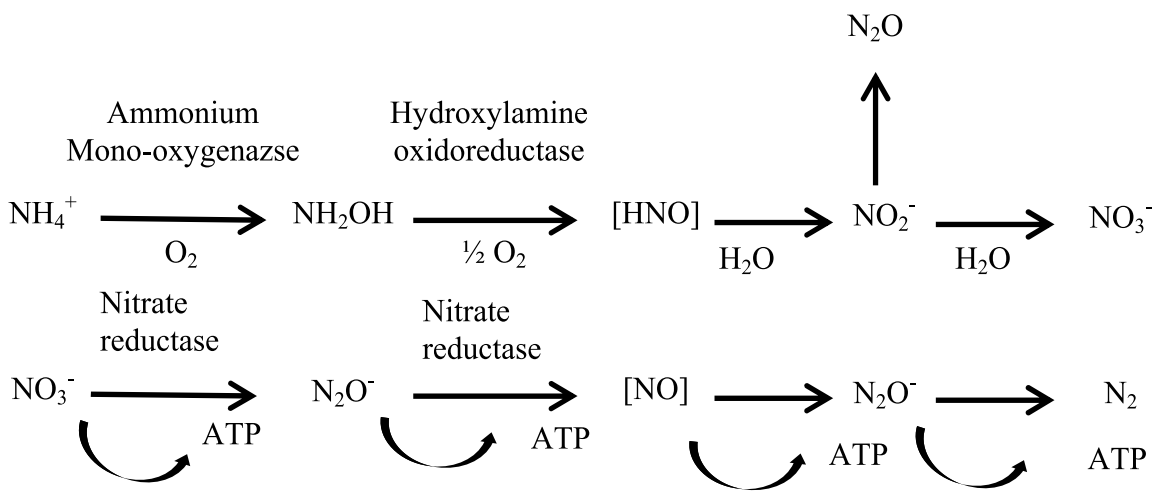

\section{GHG measurement methods}

\subsection{Measurements of Greenhouse gas concentrations}

Uncertainties in the accurate emission estimate are mainly dependent on the errors associated with sampling protocol and devices and gas analyzers. Thus, the validation of emission inventories using emission measurements is extremely important as well as source-related emission measurements that are feeding emission inventories. To develop GHG mitigating strategies, it is required to quantify GHG emissions from livestock operations under a wide range of productions and management circumstances. Gases at trace levels can be measured using different techniques. GHGs can be measured using infrared spectroscopy (IR), photoacoustic spectroscopy (PAS), gas chromatography (GC), 
mass spectroscopy (MS), tunable diode laser absorption spectroscopy (TDLAS) technology, open path Fourier Transform Infrared Radiation (OP-FTIR) technologies, and solid-state electro-chemical technology. Instruments with mass spectrophotometers have very rapid response, can detect many gases at one time, and exhibit linear responses over a wide range of concentrations, while behaving very accurately and with stability. However, mass spectrophotometers, TDLs, and OP-FTIRs are expensive. Solid state electrochemical sensors are relatively inexpensive but they are unstable and require frequent calibration. The shelf lives of those sensors also vary from 12-18 months.

\subsection{Flux measurement process at the ground level of the livestock facilities}

The GHG emission estimation from different ground level area sources (GLAS) of manure managements in livestock operations such as lagoons (primary and secondary), barns, settling basins, silage piles, loafing pens, feedlots pens, compost windrows, and crop/pasture land is a very complicated process. Generally, two basic processes such as device independent and sampling device are widely used to estimate emission from emitting surfaces. In the device-independent techniques, the emission rate (amount ( $\mathrm{g}$ or $\mathrm{kg}$ ) of compound emitted per head per day or year is estimated from the concentrations of the measured emission across the plume of emitted material using local micrometrical data, especially wind velocity profile data [56-57]. When using a sampling device, a chamber and winds tunnel is deployed on an emitting surface under some recommended operating conditions. Those devices may be static (sealed or vented) or flushed with zero grade air (containment free) at a known velocity or flow rate (known as dynamic). Generally, the emission rate is estimated as the product of concentration and air flow through the device [57-59]. There is debate about the suitability and accurateness to quantify pollutant emissions at CLOs and other area sources due to the creation of microenvironments in the chamber and the small measurement footprint relative to the size of the source [57-60]. Hudson et al. [61] compared and reported that odor emissions from a wind tunnel rates were 60 to 240 times higher than those in a flux chamber [62]. Parker et al [60,71] also demonstrated that water evaporation, wind speed, and temperature would be useful to standardize and compare emission rates from flux chamber and wind tunnels. They also suggested developing correction factors for each device, which depend on the geometry of the wind tunnel and chamber. Instruments and devices commonly used to measure gas emissions from CLOs were presented in the Table 1.

\section{GHG scrubbing technology}

In the livestock industries, End-of-Pipe technologies such as biofilters and wet scrubbers are commonly used in process-air applications i.e. potentially harmful particulates matter (PM) and pollutants in exhaust air of the housings/barns are treated. Generally, water with added active chemicals such acids and oxidizing agents $\left(\mathrm{H}_{2} \mathrm{O}_{2}, \mathrm{H}_{2} \mathrm{SO} 4, \mathrm{O}_{3}, \mathrm{kMnO}_{4}, \mathrm{HOCl}\right.$, etc) are tailored with the process to spray into the air stream coming out of the exhaust. This approach for reducing emission is basically a treatment of the exhaust air released from 
mechanically ventilated animal housings. The main advantages for this approach are air can be treated without affecting the routine management operations and structural design inside the barn. Broadly, two types of air scrubbers are presently available: acid scrubbers and bio-trickling filters. The main purpose of these scrubbers is ammonia abatement; the scrubber systems are commercially available and considered as off-shelf techniques in such as the Netherlands, Germany and Denmark [64].

\subsection{Scrubber descriptions}

\subsubsection{Spray type wet-scrubber}

In an acid scrubber for ammonia, diluted acid mainly sulfuric acid $\left(\mathrm{H}_{2} \mathrm{SO}_{4}\right)$ with $\mathrm{pH}$ of 2-4 is used to scrub ammonia from air and the ammonium salt is removed from the system with the discharge water. Spray scrubbers consist of empty cylindrical or rectangular chambers in which the gas stream is contacted with liquid droplets generated by spray nozzles. The spray nozzles (hydraulically or air or steam atomized), are used to extend the surface area of the scrubbing liquid and produce target droplets size that facilitates mass transfer of the contaminants gas(es) into liquid. They are mainly used for gas absorption. Particulate matters (PMs) and gaseous pollutants in the air stream are removed by either absorption or chemical reactions with the water solution. PM and pollutions from the scrubber process are removed periodically through the drain. Schematic of a typical spray nozzle scrubber configuration along with system components is shown in the Figure 3.

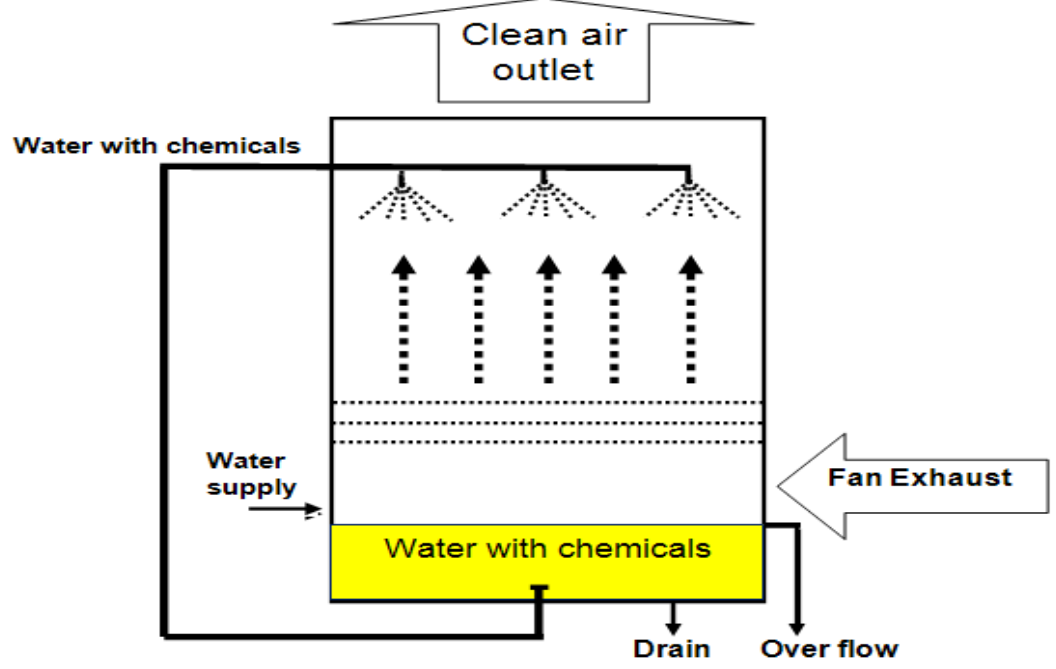

Figure 3. Schematic diagram spray type wet-scrubber system 


\subsubsection{Packed bed wet-scrubber}

A packed tower air scrubber or bio-trickling filter is a reactor that is filled with an inert or inorganic packing material. The packing material usually has a large porosity, or void volume, and a large specific area [64]. Water with added a chemicals is sprayed either continuously or intermittently from the top of the packed bed to keep it wet. The contact between the air and water, facilitates a mass transfer from soluble gases to a liquid phase when exhaust air is introduced wither horizontally (cross-current) or upwards (countercurrent). A fraction of the trickling water is continuously recirculated, while another fraction is discharged and replaced by fresh water [65]. Schematics of typical spray nozzle scrubber and packed bed acid scrubbers configuration along with system components is shown in Figure 4.
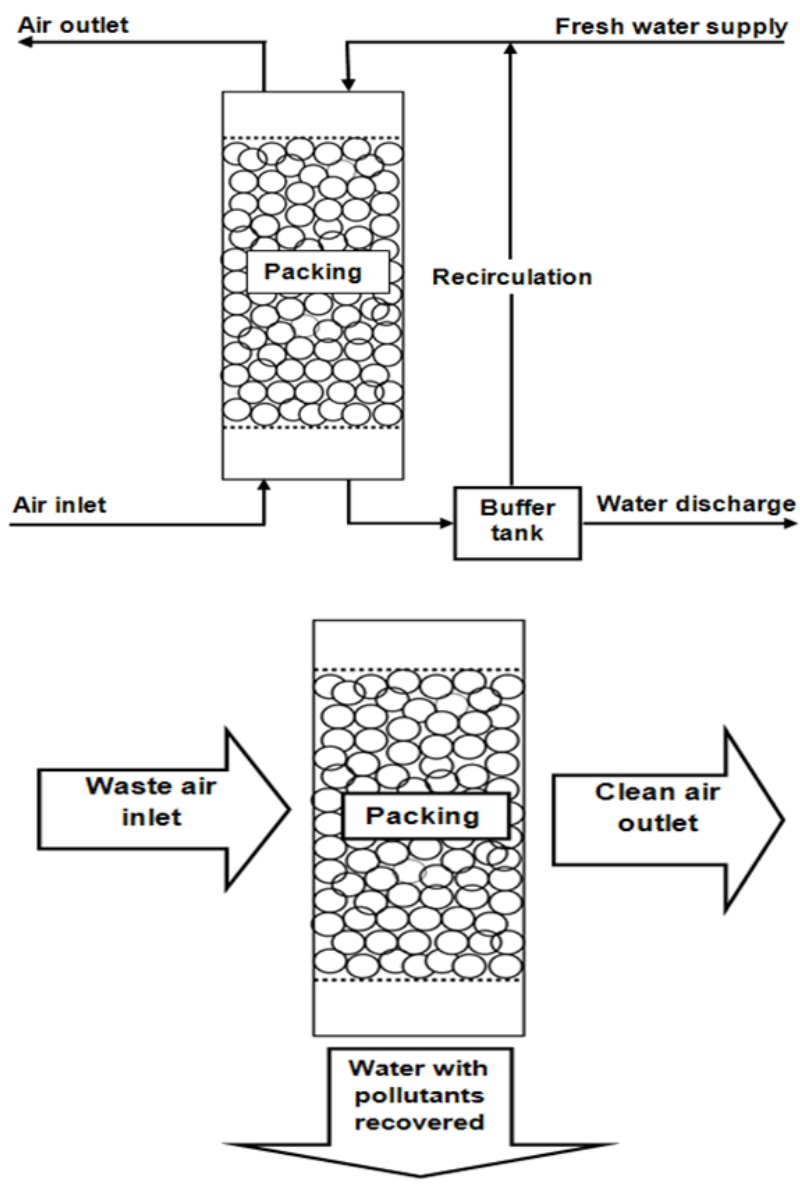

Figure 4. Schematic diagrams of packed bed trickling filters: top) counter current packed wet-scrubber, and bottom) cross current (adopted from [64-65). 


\subsubsection{Pollutants removal efficiency calculation}

Gaseous pollutants removal efficiency is generally used as the criteria for determining the spray type wet scrubber performance can be defined as [66]:

$$
\gamma_{\text {total }}=\frac{C_{\text {in }}-C_{\text {out }}}{C_{\text {in }}} \times 100
$$

Where:

$\gamma_{\text {total }}=$ Pollutant collection efficiency $(\%)$

$C_{\text {in }} \quad=$ Airborne Pollutant concentration before the scrubber (ppm)

$C_{\text {out }} \quad=$ Airborne Pollutant concentration after the scrubber (ppm)

Similarly, the difference in the weight of the PM filters before and after scrubber sampled during 24 hours and the standardized airflow were used to calculate the average PM10 concentration. The details on the used method for PM10 determination can be found in [67]. For wet-scrubbers, the air flow rate is used to calculate average Empty Bed air Residence Time (EBRT). The air flow rate through the scrubbers can be determined either by measuring fans or by means of a $\mathrm{CO}_{2}$ balance method [68]. The EBRT can be defined as follows:

$$
E B R T=\frac{\text { Packing volume }\left(m^{3}\right)}{\text { Air flow rate }\left(m^{3} s^{-1}\right)} \times 100
$$

\subsection{Wet scrubber applications in AFOs}

The development of wet air-scrubbers for mitigating air emissions from CLOs has started a longtime ago. To begin with, wet scrubbers were employed to reduce odor and particulates being discharged from livestock facilities [69-70]. Later on, scrubbing other airborne contaminants such as $\mathrm{NH}_{3}[66,71,65], \mathrm{H}_{2} \mathrm{~S}$ [72], and pathogens [73] were also investigated to test their scrubbing efficacy. The collection efficiencies reported ranging minus to $100 \%$ for odor, $23 \%$ to $96 \%$ for $\mathrm{NH} 3$, and $36 \%$ to $96 \%$ for particulate matter. An acid scrubber and a bio-trickling filter (BTF) were developed to reduce ammonia and odor from swine and poultry houses in the Netherland. Melse and Ogink [71] reported an average ammonia removal efficiency of $96 \%$ in acid scrubbers (ranging from $40 \%$ to $100 \%$ ). The average efficiency estimated using the air balance method was $71 \%( \pm 4 \%)$. At least 24 measurement days are recommended to keep the relative error below $5 \%$ when using the air balance method in determining the $\mathrm{NH}_{3}$ removal efficiency of an acid packed bed scrubber [65].

Chemical scrubbers and bio-scrubbers have shown tremendous potentials in reducing high particulates and ammonia, however, are not very effective in removing typical odors [74-75]. The major limitations encountered in the development of wet scrubber technology for CLOs are low collection efficiency of the odorous compounds, high pressure drop, and high operating costs. An acid spray wet scrubber has the greatest potential for adaptation to existing swine facility ventilation fans because they do not cause excessive backpressure to the fans and do not significantly reduce building ventilation airflow [66]. 
Recent literature showed that the majority of scrubbers designed for CLO applications were employed for removing ammonia. In Europe, the most common commercial scrubbers are packed-type, which can be bought off the shelf are for application at CLOs [76] and have been proven to effectively remove $\mathrm{NH}_{3}$ by up to $96 \%$, but their packing material resulted in large pressure drop [71]. Other types of wet scrubbers such as impingement plate, fiber bed 71], and rotating beds [77] have been used for $\mathrm{NH}_{3}$ collection. These wet scrubbers also resulted high pressure drop and did not work well with the existing ventilation systems of AFOs because axial fans are typically used for movement of large volume of airflow under small differential static pressure conditions. Recently, a new generation multi-pollutants scrubbers have also been developed to address ammonia, odor, and particulates abatement released from livestock operations. This scrubber mainly consist of two or more scrubbing stages (combining the concepts of acid scrubbing, bio-scrubbing, and bio-filtration), each stage aims for the removal of one type of compound [78]. Three multi-stage scrubbers, one double-stage scrubber (acid stage+ bio-filter), one double-stage scrubber (acid stage + bioscrubber), and one triple-stage scrubber (water stage + acid stage + bio-filter) were evaluated to test their effectiveness in reducing airborne dust, total bacteria, ammonia, and $\mathrm{CO}_{2}$ emissions from swine houses in Netherlands. Those scrubbers reduced PM10, PM2.5, total airborne bacteria, and ammonia emissions from 61 to $93 \%, 47$ to $90 \%, 46$ to $85 \%$, and 70 to $100 \%$, respectively [79]. Concentrations of $\mathrm{CO}_{2}$ were not affected.

Most scrubbing technologies for CLOs are still in the developmental stages in the US. The major limitations encountered in the development of wet scrubber technology for CLOs are low efficiency, high pressure drop, and high operating costs. The spray-type wet scrubbers usually are generally shown low collection efficiency for $\mathrm{NH}_{3}$ gas $[80,70]$. A spray scrubber with water has shown to be a collection efficacy of approximately $20 \%$, although, ammonia is fairly water soluble $20 \%$ [81]. Higher $\mathrm{NH}_{3}$ absorption can be achieved by spraying diluted acidic solution as a scrubbing liquid [73]. In addition, use of acidic substances for collecting ammonia is highly preferred because of its great potential to get the $\mathrm{NH}_{3}$ recycled into liquid fertilizer. Ohio state university has developed spray wet scrubber and three of those were installed on a commercial deep-pit swine building, a poultry manure composting facility, and a covered swine manure storage, respectively. The field tests of the wet scrubber showed an ammonia collection efficiency up to $98 \%$ and $80 \%$ for exhaust air with low (5 ppmv) and high ammonia concentrations (200 ppm), respectively. However, it is not tested for GHG mitigation.

\subsection{Biofilters}

Biofiltration is an air-cleaning process which absorbs pollutant gases and particulates into a biofilm on the filter media. Microorganisms in the filter media degrade and break the volatile organic compounds (VOC) and oxidizable inorganic gases. Selection of a proper biofilter media is a critical factor for developing an efficient biofilter. These factors such as optimum environment for microorganisms (moisture, temperature, porosity, etc.), large surface area to maximize attachment area and sorption capacity, stable compaction properties, high moisture holding capacity, high pore space to maximize empty bed 
residence time (EBRT), and minimize pressure drop [72]. Recently, Chen et al. [72] evaluated a pilot-scale wood chip-based (e.g., western cedar and hardwood) biofilter to reduce odor, $\mathrm{H}_{2} \mathrm{~S}$, and $\mathrm{NH}_{3}$ from swine barn ventilation air for 13 weeks. They found that hardwood and western cedar biofilters can remove odor by 70.1 and $82.3 \%$, respectively, and $\mathrm{H}_{2} \mathrm{~S}$ by 81.8 and $88.6 \%$, respectively. Biofilters saturate easily [82] and large pressure drops across them making it difficult for them to be adopted by animal facilities. Difficulty also rests with the stringent moisture and temperature requirements for the process and more frequent media replacement [83]. It reported that biofilters may not be suitable to reduce high odor concentrations due to nitrogen accumulation in the biofilter material that causes the release of other pollutants including nitrous oxide $\left(\mathrm{N}_{2} \mathrm{O}\right)$, a highly potent greenhouse gas [74]. The biofiltration is a simple technology but requires careful monitoring of operating parameters for treating contaminated air effectively. However, microbial process taking place in the filter beds are very complicated, which depends on few environmental and physical factors as summarized below [82,84]:

High ammonia loads generally trigger excessive nitrite/nitrate concentrations that inhibit a proper functioning of micro-organisms in the filter bed and leads to acidification which forms nitrite/nitrate salts. This in turn, declines the removal efficiency of the filter. Thus, by replacing saturated biofilter packing at regular interval this issue can be addressed.

Maintaining adequate moisture in the filter bed is the critical factor for proper functioning by the filter because of drying out inlet side of the filter bed when relatively dry air is coming out of the exhaust housings. Thus, the biofilter bed has to be kept moist to ensure proper microbial functioning.

Biofilters are inherently prone to dust loads, thus, clogging the packing bed and increasing the pressure drop. The total pressure drop over the filter bed can be very high and in practice it is $>200-300 \mathrm{~Pa}$. This clogging when coupled with inadequate moisture in the filter bed may lead to reduced air flow which will decrease overall scrubbing performance of the filter bed. These in turn need an increase in energy input unit of air volume handled. The functional lifespan of the biofilter can be enhanced by pre-treating incoming air, routing it first through an acid scrubber and mist eliminator before entering the biofilters.

Thus, design and operational parameters such selection of packing material, maintaining optimum moisture content, weed control and assessing pressure drop are very critical for efficient operation of the biofilters. The functional lifespan of the biofilter can be enhanced by pre-treating incoming air, routing it first through an acid scrubber and mist eliminator before entering the biofilters.

\subsection{GHG scrubbing technology}

Existing GHG mitigation options related to manure management are focused on feed manipulation, animal management, and processes to treat and manage animal manure. GHG emitted from animal buildings, especially swine buildings with deep pits and dairy buildings, accounted for a large portion of GHG emission. However, mitigation technologies 
for GHG emissions from these animal buildings are lacking. Recent adaptation of mechanical ventilation systems for these buildings made it possible for better maneuvering the air stream in routing it through a suitable scrubbing system. Gaseous emissions including methane must be reduced before it escapes into the atmosphere. Housings or sources with mechanical exhaust ventilation systems are advantageous for capturing methane emission before it enters the atmosphere. However, this process inherently needs to handle large quantities of exhaust/ ventilation air at low cost. Thus, higher energy requirement to process huge amount of exhaust may not be economically feasible. Therefore, it is urgently needed to develop effective and economically feasible GHG mitigation technologies for the reduction of these emissions from animal barns to ensure sustainable and viable swine and dairy industries.

Nitrous oxide $\left(\mathrm{N}_{2} \mathrm{O}\right)$ and $\mathrm{NH}_{3}$ are fairly soluble in a wide variety of solvents including water, alcohols, sulfuric acid, etc.). Unlike ammonia and $\mathrm{N}_{2} \mathrm{O}, \mathrm{CH}_{4}$ is highly insoluble in water, and thus, scrubbers developed for $\mathrm{NH}_{3}$ cannot be used for mitigating $\mathrm{CH}_{4}$. Methane is a very stable molecule at ambient temperatures so it cannot be removed by many of the scrubbing techniques that are used for other gases. It has been previously shown in rendering facilities that oxidants like chlorine dioxide are effective for the removal of VOCs and other organic compounds using exhaust wet scrubbers. However, these may be expensive when applied as scrubbing liquid for swine facilities. In swine pits and dairy buildings, $\mathrm{CH}_{4}$ concentrations are too lean to burn; oxidation by scrubbing can be an effective and safe alternative for reducing $\mathrm{CH}_{4}$ emissions. This situation warrant researching alternative scrubbing liquids to make the $\mathrm{CH}_{4}$ scrubbing process economically feasible. Other possible oxidants such as hydrogen peroxides $\left(\mathrm{H}_{2} \mathrm{O}_{2}\right)$, Ozone $\left(\mathrm{O}_{3}\right)$, potassium permanganate $\left(\mathrm{KMnO}_{4}\right)$, and hypochlorus acid $(\mathrm{HOCl})$, etc) can be tested to reduce $\mathrm{CH}_{4}$ in a suitable scrubber. Ozone, a strong oxidant, has been used extensively to improve air and water quality. It has also been used by agricultural engineers to control air quality in animal buildings [85,86]. Ozonating water has been proven to effectively oxidize organic compounds dissolved in water. Transfer of organic compounds from air to water by spray scrubber absorption is very promising for the capture of GHG, and deodorizing and sanitizing air without affecting the CLOs ventilation system. It is well known that ozone reacts with methane either in presence of ultraviolet (UV) light or high temperature. Therefore, to explore the methane reduction in a cost effective manner, a spray type wet scrubber can be tested with ozonated water (or other effective oxidants) and UV light. The scrubbing system can be consisted of a spray-wet-scrubber column made from a material (either glass or acrylic) with high UV light transmittance, flow control meters, an ozone generator, and oxidant liquid supply and collection systems. A dust cleaning system needs to be incorporated to allow UV light to always pass through the scrubber.

\section{Management practices to reduce GHG emissions}

Methane from enteric fermentation, manure storage and spreading, and nitrous oxide mainly from application of manure on land are the major sources of agricultural GHG emission. Prior to being applied to crop or pasture field, manure from CLOs is generally 
stored in a liquid or solid form. For most cases, in order to produce $\mathrm{CH}_{4}$ gas to use as biofuel, manure is anaerobically digested or composted before land application. By adapting manure management and treatment practices to enable methane collection, methane emissions from anaerobic digestion can be recovered and used as energy. Anaerobic digestion provides an appropriate environment for the complete degradation of organic matter to low-odor end products [[87]. It also produces methane (biogas), which can be used for the production of electricity and heat [10]. However, due to high content of ammonia, the digestion of only swine manure was not favorable [85,88]. Generally, $\mathrm{CH}_{4}$ mitigation approaches can be broadly divided into four categories as follows:

1. Preventative or feed management

2. Manure managements including treatment process and land application methods

3. Adaptation of housing system design including inside manure storage

4. End of pipe air treatment.

\subsection{Preventive method (feed management)}

Preventative measures are the reduction in carbon/nitrogen inputs into the system of animal husbandry through a dietary manipulation to achieve reduced $\mathrm{CH}_{4}$ production. An effective tool to reduce nutrient/mineral pollution and GHG emissions is proven to be dietary manipulation. Numerous studies have revealed that reducing crude protein in the diet could substantially lessen nitrogen excretion and ammonia volatilization without compromising productivity [89-93]. Hao et al. [94] studied the effects of DDGS on feces and manure composition in feedlot cattle and revealed that as the ratios of wheat DDGS (e.g., 0 , 20, 40, and 60\%) in animal diet increased (40 and 60\% wheat DDGS), the likelihood of volatile fatty acids (VFAs) also increased. This led to the growth of odors produced from the breakdown of fiber and protein [89]. They suggested that it might be a practicable option to obtain $20 \%$ or less DDGS in animal diet to limit VFAs produced from the breakdown of fiber and protein [89]. Enteric fermentation produced approximately $80 \%$ of the $\mathrm{CH}_{4}$ produced from ruminants. The chemical composition of diet is a vital feature, which affects rumen fermentation and methane emission by the animals. Furthermore, dietary manipulation also impacts the amount of GHG emissions, particularly from enteric fermentation. For example, feeding cattle with a high starch and low fiber diet reduces creation of acetate in the rumen and leads to lower methane production [93]. As a proportion of energy intake, a higher proportion of concentrate in the diet leads to a reduction in $\mathrm{CH}_{4}$ emissions. Stored manure and high fiber fed animals tend to have higher emissions. Diet affecting emissions from manure applied soil has significant evidence. Replacing fibrous diets by starchy feedstuff has been shown to reduce methane from enteric fermentation and manure storage [95-96]. As the level of production is increased to meet global demand for ruminant meat and milk products, dietary manipulation will be useful in addressing environmental concerns. Sejian and Naqvi [7] described enteric methane reduction strategies under four categories as shown in Figure 5. Likewise, a detailed evaluation of mitigation options of methane emissions from enteric fermentation is presented in Table 5 [97]. Abatement of GHG emissions from ruminant animals has been focused on diet, rumen and animal 
manipulations, such as improving forage quality, adding dietary supplement, reducing unproductive animals, and supplementing probiotics to change microbial population in rumen [96]. Dietary fat seems a promising alimentary alternative to depress ruminal methanogenesis without lessening ruminal $\mathrm{pH}$ as opposed to concentrates [98]. Beauchemin et al. [99] recently reviewed the effect of level of dietary lipid on $\mathrm{CH}_{4}$ emissions over 17 studies and reported that with beef cattle, dairy cows and lambs, for every $1 \%$ (DMI basis) increase in fat in the diet, $\mathrm{CH}_{4}(\mathrm{~g} / \mathrm{kg} \mathrm{DMI})$ was reduced by $5.6 \%$.

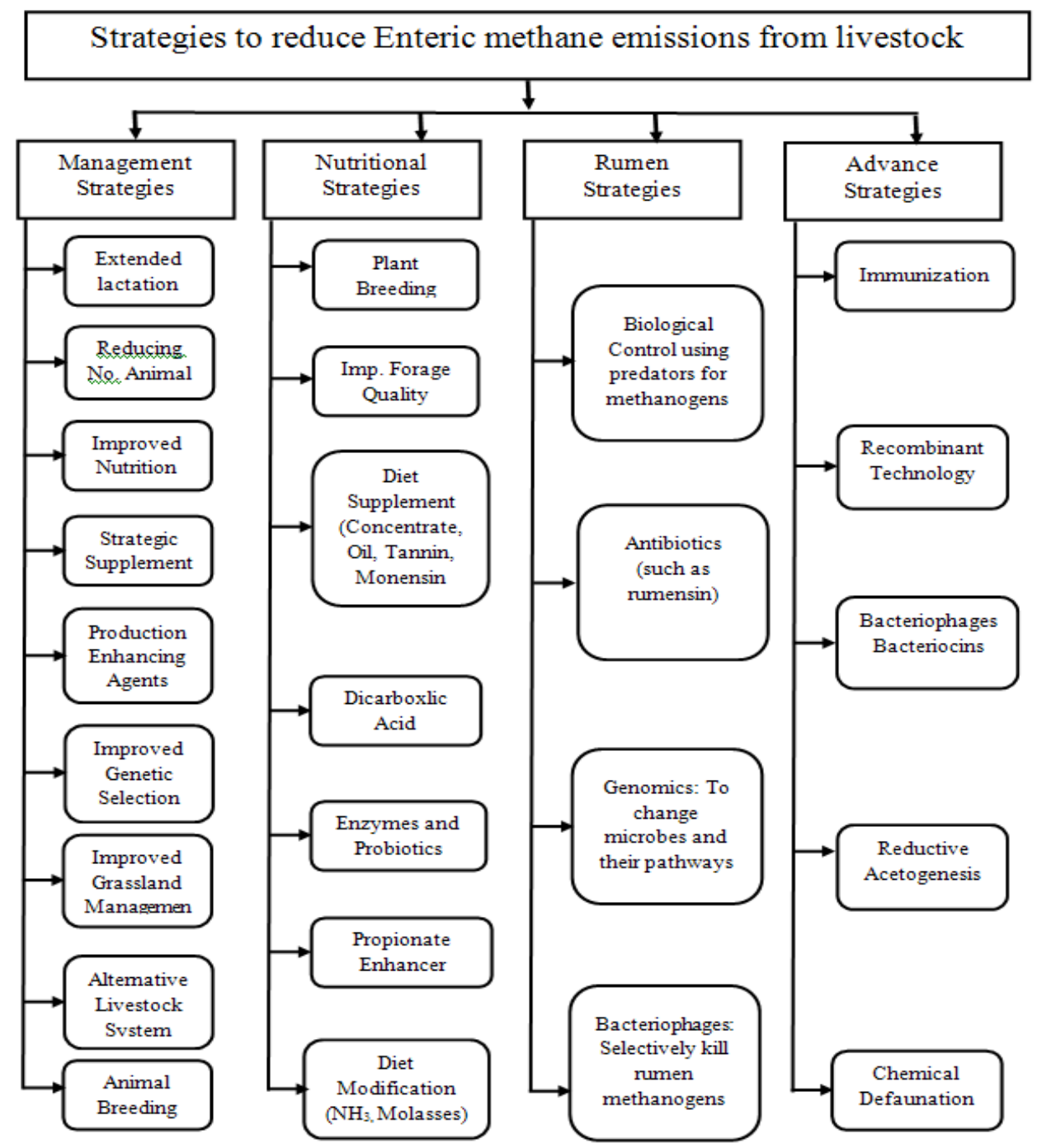

Figure 5. Different enteric methane mitigation strategies [7] 


\begin{tabular}{|c|c|c|c|}
\hline Strategy & $\begin{array}{l}\text { Potential } \mathrm{CH} 4 \\
\text { reduction }\end{array}$ & Technology/feasibility & Cost/production benefits \\
\hline $\begin{array}{l}\text { Improving animal } \\
\text { productivity }\end{array}$ & $20-30 \%$ & Feasible and practical & $\begin{array}{l}\text { Increased feed cost } \\
\text { increased milk } \\
\text { production } \\
\text { use of fewer animals } \\
\text { less feed per kg of milk }\end{array}$ \\
\hline $\begin{array}{l}\text { Increasing } \\
\text { concentrate levels at } \\
\text { high levels of intake }\end{array}$ & $25 \%$ and more & $\begin{array}{l}\text { Feasible, for high producing } \\
\text { cows, but may increase } \mathrm{N}_{2} \mathrm{O} \\
\text { and } \mathrm{CO}_{2} \text { emissions }\end{array}$ & $\begin{array}{l}\text { Increased feed cost } \\
\text { increased milk } \\
\text { production } \\
\text { use of fewer animals } \\
\text { less feed per kg of milk } \\
\text { production } \\
\end{array}$ \\
\hline $\begin{array}{l}\text { Processing of forages, } \\
\text { grinding/pelleting }\end{array}$ & $20-40 \%$ & Feasible & $\begin{array}{l}\text { Increased cost of } \\
\text { processing } \\
\text { improved feed efficiency } \\
\text { increased milk } \\
\text { production } \\
\end{array}$ \\
\hline $\begin{array}{l}\text { Forage species and } \\
\text { maturity }\end{array}$ & $20-25 \%$ & Feasible & $\begin{array}{l}\text { Increased feed efficiency } \\
\text { increased milk } \\
\text { production }\end{array}$ \\
\hline $\begin{array}{l}\text { Rotational grazing of } \\
\text { animals/early grazing }\end{array}$ & $9 \%$ or more & Feasible & $\begin{array}{l}\text { Increased cost of fencing } \\
\text { increased management } \\
\text { of animals } \\
\text { increased feed intake } \\
\text { increased milk } \\
\text { production } \\
\end{array}$ \\
\hline $\begin{array}{l}\text { Managed intensive } \\
\text { grazing vs. confined } \\
\text { feeding }\end{array}$ & & $\begin{array}{l}\text { Feasible need more } \\
\text { investigation }\end{array}$ & $\begin{array}{l}\text { Cheaper feed cost } \\
\text { may need supplements } \\
\text { reduced milk fat/protein } \\
\text { content } \\
\text { higher net return } \\
\end{array}$ \\
\hline $\begin{array}{l}\text { Use of high quality } \\
\text { forages/pastures }\end{array}$ & $25 \%$ or more & Feasible & $\begin{array}{l}\text { Increased feed intake } \\
\text { increased milk } \\
\text { production }\end{array}$ \\
\hline $\begin{array}{l}\text { Preservation of forage } \\
\text { as silage vs. } \\
\text { hay/additives }\end{array}$ & $\begin{array}{l}\text { up to } 33 \% \text { (model } \\
\text { prediction) }\end{array}$ & Feasible & Limited studies \\
\hline Addition of fats & up to $33 \%$ & $\begin{array}{l}\text { Feasible and practical, but } \\
\text { usage limited to } 5-6 \% \text { in diet }\end{array}$ & $\begin{array}{l}\text { Increased cost of diet } \\
\text { increased or no effect on } \\
\text { milk } \\
\text { production } \\
\text { may or may not affect } \\
\text { milk fat }\end{array}$ \\
\hline
\end{tabular}




\begin{tabular}{|c|c|c|c|}
\hline Strategy & \begin{tabular}{|l|}
$\begin{array}{l}\text { Potential } \mathrm{CH} 4 \\
\text { reduction }\end{array}$ \\
\end{tabular} & Technology/feasibility & Cost/production benefits \\
\hline $\begin{array}{l}\text { Use of ionophores, } \\
\text { e.g., monensin, } \\
\text { lasolocid }\end{array}$ & $11-30 \%$ & $\begin{array}{l}\text { Feasible but long lasting } \\
\text { public concern }\end{array}$ & $\begin{array}{l}\text { Increased feed efficiency } \\
\text { decreased feed intake } \\
\text { increased milk } \\
\text { production }\end{array}$ \\
\hline Use probiotics & $10-50 \%$ (in vitro) & $\begin{array}{l}\text { Feasible, needs more } \\
\text { investigation }\end{array}$ & $\begin{array}{l}\text { May increase feed intake } \\
\text { may increase milk } \\
\text { production } \\
\text { or no change }\end{array}$ \\
\hline Use of essential oils & $8-14 \%$ & $\begin{array}{l}\text { Feasible, needs more } \\
\text { investigation }\end{array}$ & Not quantified \\
\hline $\begin{array}{l}\text { Use of bovine } \\
\text { somatotropin (bST) }\end{array}$ & $9-16 \%$ & $\begin{array}{l}\text { Not approved for use in } \\
\text { Canada }\end{array}$ & Reduced feed cost \\
\hline Protozoa inhibitors & $20-50 \%$ & $\begin{array}{l}\text { Not available for practical } \\
\text { use }\end{array}$ & $\begin{array}{l}\text { Practically and cost to be } \\
\text { assed }\end{array}$ \\
\hline $\begin{array}{l}\begin{array}{l}\text { Propionate enhancers } \\
\text { (fumarate, malate) }\end{array} \\
\end{array}$ & $\begin{array}{l}5-11 \% \text { (in vitro) } \\
\text { up to } 23 \% \text { (in } \\
\text { vivo) }\end{array}$ & $\begin{array}{l}\text { Possible microbial } \\
\text { adaptation to fumaric acid }\end{array}$ & $\begin{array}{l}\text { Economic feasibility } \\
\text { ruminal adaptation and } \\
\text { level of } \\
\text { inclusion need to be } \\
\text { evaluated }\end{array}$ \\
\hline \begin{tabular}{|l|} 
Use of acetogens \\
\end{tabular} & not quantified & $\begin{array}{l}\text { Not available, needs more } \\
\text { investigation }\end{array}$ & $\begin{array}{l}\text { Needs further } \\
\text { investigation }\end{array}$ \\
\hline $\begin{array}{l}\text { Use of bacteriocins, } \\
\text { e.g., Nisin, bovicin } \\
\text { HC5 }\end{array}$ & $\begin{array}{l}\text { up to } 50 \% \text { (in } \\
\text { vitro) }\end{array}$ & $\begin{array}{l}\text { May provide alternatives to } \\
\text { ionophores needs more } \\
\text { investigation }\end{array}$ & $\begin{array}{l}\text { Production effects are to } \\
\text { be evaluated }\end{array}$ \\
\hline $\begin{array}{l}\text { Use of methane } \\
\text { inhibitors, e.g., } \\
\text { BES, 9,10- } \\
\text { anthraquinone }\end{array}$ & $\begin{array}{l}\text { up to } 71 \% \text { (in } \\
\text { vitro) }\end{array}$ & $\begin{array}{l}\text { No compounds registered } \\
\text { for use } \\
\text { No long lasting effects } \\
\text { identified }\end{array}$ & $\begin{array}{l}\text { Increased cost of } \\
\text { chemicals } \\
\text { production effects not } \\
\text { established }\end{array}$ \\
\hline Immunization & $11-23 \%$ & $\begin{array}{l}\text { Not available, needs more } \\
\text { investigation }\end{array}$ & $\begin{array}{l}\text { May increase cost of } \\
\text { production } \\
\text { increased gain }\end{array}$ \\
\hline $\begin{array}{l}\text { Genetic selection (use } \\
\text { of high Net Feed } \\
\text { Efficiency animals) }\end{array}$ & $21 \%$ & Long term feasibility & $\begin{array}{l}\text { May increase cost of } \\
\text { production } \\
\text { increased gain }\end{array}$ \\
\hline
\end{tabular}

Table 5. Summary of methane mitigation strategies for dairy cows [97]

\subsection{Manure management}

It is well known that GHG emissions (mainly $\mathrm{CH}_{4}$ and $\mathrm{N}_{2} \mathrm{O}$ ) from manure differ significantly depending on the management system employed to process them. Therefore, 
strategies for mitigating net GHG emissions should be aimed to manipulate manure properties or the conditions under which $\mathrm{CH}_{4}$ and $\mathrm{N}_{2} \mathrm{O}$ are produced and utilized during manure storage and treatment. However, GHG mitigation options are critical and depend on several factors. These factors are economic, technical and material resources, climatic conditions, existing manure management practices, bio-energy sources, and a source of high quality fertilizer and soil amendments. One such approach is to manipulate livestock diet composition and/or include feed additives to alter manure $\mathrm{pH}$, concentration and solubility of carbon and nitrogen, and other properties that are pertinent to $\mathrm{CH}_{4}$ and $\mathrm{N}_{2} \mathrm{O}$ emissions [7]. Nitrogen excreted in urine is predominant in the form of urea that can easily be converted into ammonia and carbon dioxide by the enzyme urease (which is present in feces), thus resulting in emission of ammonia. Nitrogen excreted in feces is mainly present as protein, which is less susceptible to decomposition into ammonia [64]. Therefore, feed management aims at either reducing the nitrogen excretion in feces and urine by matching the amount and composition of feed more closely to animal requirements at various production stages, or shifting nitrogen excretion from urine to feces by increasing fibrous feedstuffs in the diet [64]. The use of these strategies can reduce the ammonia emission both for pigs [100-101], poultry [102-104] and dairy cattle [105-106]. About 50\% of ammonia emissions to the environment were reduced through feed management for pigs and poultry when compared to standard feed composition. However, feed manipulation for ammonia abatement may negatively affect the emission of methane and nitrous oxide during storage and after land application of the manure [107].

Another manure management option is to change the material used for bedding the animals, which could also affect manure $\mathrm{pH}$ and soluble $\mathrm{C}$ and $\mathrm{N}$ levels and thus, the emissions during manure storage and treatment. Composting technology, control of aeration, use of amendments, or co-composting livestock manure with other organic waste could also potentially modify conditions for GHG production and emission. The use of covers may also help retain $\mathrm{N}$ nutrients during storage. Floating covers of natural and synthetic, origin or composites of both have shown substantial reduction in $\mathrm{NH}_{3}$ and $\mathrm{H}_{2} \mathrm{~S}$ emissions when compared with uncover liquid manure. However, little is known about the effect of covers on GHG emissions. In a two week study, covers generally increased $\mathrm{CO}_{2}$ and $\mathrm{CH}_{4}$ emissions [108].

\subsubsection{Animal population and low $N$ grass}

A large part of $\mathrm{N}$ from animal waste and farm effluents is lost to the environment as excess $\mathrm{NH}_{3}$ or $\mathrm{N}_{2} \mathrm{O}$ from urine spots and animal manures instead not being recovered in livestockproduction systems. There are various options for reducing $\mathrm{NH}_{3}$ and $\mathrm{N}_{2} \mathrm{O}$ emissions from livestock facilities, but the most significant option is to improve overall $\mathrm{N}$ efficiency. By reducing the livestock numbers, the amount of excreta would be reduced, hence the amount of emissions. Another mitigation option would be to manipulate the $\mathrm{N}$ economy of the animal to reduce $\mathrm{N}$ excretion. A lower $\mathrm{N}$ content of pasture or silage would reduce $\mathrm{N}$ 
excretion by animals and $\mathrm{NH}_{3}$ volatilization loss [43]. Excretal $\mathrm{N}$ could be reduced by using grass grown with moderate fertilizer application [93].

\subsubsection{Anaerobic digestion and gas capture}

With the use of liquid-based livestock facilities, the primary method for reducing emissions is to recover the methane before it is emitted into the air. Methane recovery involves capturing and collecting the methane produced in the manure management system. This recovered methane can be flared or used to produce heat or electricity. Because most of the manure facility methane emissions occur at large confined animal operations (primarily dairies and hog farms), the most promising options for reducing these emissions involve recovering the methane at these facilities and using it for energy. Additionally, in the effluent management systems, where the animal waste is gathered and/or stored in a covered digester lagoon and permitted to decay anaerobically, farmers are allowed to collect the generated $\mathrm{CH}_{4}$ for heating and bio-energy use. Once $\mathrm{CH}_{4}$ is removed from the waste, the remaining digestate can be used as a fertilizer and soil conditioner [43]. This option saves farmers money for energy costs and reduces $\mathrm{CH}_{4}$ emissions to the atmosphere [109]. Additionally, during anaerobic digestion of the waste/manure, $\mathrm{N}_{2} \mathrm{O}$ emission is negligible since $\mathrm{N}_{2} \mathrm{O}$ is formed during aerobic nitrification and anaerobic denitrification [40]. This is an important $\mathrm{N}_{2} \mathrm{O}$ mitigation option which reduce $\mathrm{N}_{2} \mathrm{O}$ emission in the farming system as follows [43]: (1) reduce the total amount of excreta $\mathrm{N}$ returned to pasture; (2) increase the efficiency of excreta and/or fertilizer $\mathrm{N}$; and (3) avoid soil conditions that favor $\mathrm{N}_{2} \mathrm{O}$ emissions

\subsubsection{Land application}

GHG emissions from animal manure and wastewater management systems are influenced by different physicochemical and biological factors. The key factors responsible for $\mathrm{CH}_{4}$, $\mathrm{CO}_{2}$, and $\mathrm{N}_{2} \mathrm{O}$ emissions are soil moisture, temperature, manure loading rates by the animal, depth of manure in the pen, redox potential, available $C$, diets, and microbial process. Limited studies on the overall impact of effluent application on the whole suite of gaseous emissions have indicated different effects on the emissions of greenhouse gasses. For example, injecting slurry into soil may reduce $\mathrm{NH}_{3}$ emissions. In contrast, such slurry incorporation into the soil may trigger $\mathrm{N}_{2} \mathrm{O}$ emissions. Similarly, anaerobic digestion of effluents and its subsequent land application can reduce $\mathrm{N}_{2} \mathrm{O}$ emission. However, under anaerobic condition with substrate $\mathrm{pH}$ may increase higher $\mathrm{NH}_{3}$ emissions and also higher emissions of $\mathrm{CH}_{4}$. On the other hand, the direct applications of animal waste either solids or liquid form to pasture and/or crop land can result in $\mathrm{CH}_{4}$ emissions. Additionally, this method is prone to $\mathrm{N}$ losses, and up to $90 \%$ of manure $\mathrm{N}$ losses occur in various forms, including $\mathrm{N}_{2} \mathrm{O}$. Ammonia $\left(\mathrm{NH}_{3}\right)$ also acts as a precursor for $\mathrm{N}_{2} \mathrm{O}$ and $\mathrm{NO}$ production when emitted from animal excreta [110] and thus, any approach mitigating $\mathrm{NH}_{3}$ will also reduce $\mathrm{N}_{2} \mathrm{O}$ emissions. Brink et al. [111] reported that $\mathrm{NH}_{3}$ abatement may have a contrasting effect on $\mathrm{N}_{2} \mathrm{O}$ emissions, while abatement of $\mathrm{N}_{2} \mathrm{O}$ results in a net decrease in $\mathrm{NH}_{3}$ volatilization. 
Application of swine slurry to crop/pasture field resulted the high emissions of gaseous $\mathrm{N}$, which also led to constraints on the amount of slurry $\mathrm{N}$ that can be applied per hectare of land. One potential option could be decreasing $\mathrm{N}$ content of the slurry by feeding low $\mathrm{N}$ diets. However, little work has been done on the dietary manipulation as a means of decreasing $\mathrm{N}$ losses without compromising the animal production. It was reported that a greater decrease in $\mathrm{N}$ excretion can be achieved by decreasing the crude protein $(\mathrm{CP})$ content of the diet. The denitrification rate was lower from slurry collected from pigs on low $\mathrm{CP}$ diet $\left(140 \mathrm{~g} \mathrm{~kg}^{-1} \mathrm{CP}\right)$ than a standard diet $\left(205 \mathrm{~g} \mathrm{~kg}^{-1} \mathrm{CP}\right)$, showed similar $\mathrm{N}_{2} \mathrm{O}$ emissions from both treatments [112]. Addition of available $\mathrm{C}$ to soil was previously found to increase denitrification and also the ratio of $\mathrm{N}_{2}: \mathrm{N}_{2} \mathrm{O}$ produced [113]. Therefore, higher $\mathrm{C}$ in the low$\mathrm{CP}$ diet would have favored the production of $\mathrm{N}_{2}$ rather than $\mathrm{N}_{2} \mathrm{O}$ as the product of denitrification [43]. Therefore, the abatement strategies to reduce gaseous emissions of $\mathrm{NH}_{3}$, $\mathrm{N}_{2} \mathrm{O}$, and $\mathrm{CH}_{4}$ from animal waste and farm effluents would therefore require some tradeoffs among these three gases.

\subsection{Housing system design and management}

The structure of a housing system, for example the combination of the floor-system, manure collection, and the manure removal system, largely determines the level of the emission of gaseous compounds, especially the emission of ammonia. Housing systems that reduce gaseous emissions basically comprise of at least one or more of the subsequent abatement principles [64]:

1. Reduction of emitting manure surface.

2. Fast and complete removal of the liquid manure from the pit to external slurry storage.

3. Applying an additional treatment, such as aeration, to obtain flushing liquid.

4. Cooling the manure surface.

5. Changing the chemical/physical properties of the manure, such as decreasing the $\mathrm{pH}$.

The housing systems that have been developed to include the above principles are able to reduce their gaseous (ammonia) emissions to the atmosphere from approximately $30 \%$ to $80 \%$. Brink et al [111] in Europe, estimated that while it may increase nitrous oxide emissions significantly the emission of methane was hardly affected by animal housing adaptations for ammonia abatement. Usually limited with mixed results, the effect of animal housing adaptations on odor emission was demonstrated. Furthermore, control of the indoor climate in terms of reducing air velocity at the manure surface, which decreases mass transfer at the manure-air interface [114-115], and has relatively low indoor temperatures, and results in less fouling of floors especially for pigs [116], can reduce ammonia and odor emissions to the atmosphere even further if emitting surface is reduced. The slurry-based manure management system methane emissions increase with the temperature of the stored slurry. The reduction of slurry storage temperature from 20 to $10^{\circ} \mathrm{C}$ resulted in a reduction in $\mathrm{CH}_{4}$ emissions of $30-50 \%$ [117]. In animal houses the volatilization of $\mathrm{NH}_{4}{ }^{+}$is linked to 
the ammonium $\left(\mathrm{NH}_{4}{ }^{+}\right)$concentration, the $\mathrm{pH}$ and surface area of the manure stored in the house, the area contaminated by the animals, and the temperature and ventilation of the housing system. Decreasing the surface area soiled by manure has the potential of reducing $\mathrm{NH}_{3}$ emissions. In addition, the cattle housing ammonia and $\mathrm{CH}_{4}$ emissions can be reduced through a more regular removal of manure to a closed storage system and through the systematic, everyday scraping of the floor.

\subsection{End-of-pipe air treatment}

This approach for reducing emission is basically a treatment of the exhaust air released from mechanically ventilated animal housings. The main advantages for this approach are that air can be treated without affecting the routine management operations and structural design inside the barn. End-of-pipe air treatment techniques are applied mainly for treating ammonia released from the exhaust air of livestock facilities and are commercially available off-the-shelf in the Netherlands, Germany, and Denmark [64]. The state of art of End-of-Pipe techniques and their scrubbing performance are briefly discussed in the section 4 . However, existing scrubber used for ammonia scrubbing does not scrub methane. Thus, an appropriate scrubber needs to be designed to scrub methane released from the exhausts of the animal housing or covered manure storage.

\section{Conclusions}

The livestock industry is a significant contributor to the economy of any country. More than one billion tons of manure is produced annually by livestock and poultry reared in the United States. Animal manure is a valuable source of nutrients and renewable energy in the country. On the other hand, livestock manure management is extremely challenging and resultant gaseous emissions may contribute to global warming. Livestock manure produces odor and emits GHGs such as carbon dioxide, methane and nitrous oxide that have prompted significant environmental quality degradation concerns. Major sources of agricultural GHG emissions include methane from enteric fermentation, manure storage and spreading, and nitrous oxide mainly from application of manure on land. GHG emissions from animal manure and wastewater management systems are influenced by soil/manure moisture, temperature, manure loading rate by the animal, depth of manure in the pen, redox potential, available carbon, diets, and microbial process. Mitigation options for GHG emissions are source and characteristics dependent. Mitigation of GHG emissions from animal waste must be addressed in the context of integrated waste management. Manure as a biomass goes through different chemical and biological processes for bioenergy recovery and thus, reduced methane emission. Anaerobic bio-digesters, covered lagoons or manure storages with methane flaring systems or small electricity generators are gaining popularity as viable technologies to abate GHG emissions from manure storages. In addition, since methane is generated under anaerobic conditions, switching manure management from liquid to dry manure, such as pack-bedded dairy option and hoop 
structure swine buildings with bedding, are other possibly effective management strategies to reduce methane emission. Mitigation technologies for GHG emissions released from the animal housings are lacking. Therefore, it is urgently needed that other effective and economically feasible GHG mitigation technologies be developed for the reduction of GHG emissions from CLOs to ensure improved environmental quality and sustainable and livestock agriculture in order to meet the milk and protein demand of an ever increasing world population.

\section{Author details}

Md Saidul Borhan* and Shafiqur Rahman

Agriculture and Biosystems Engineering Department, North Dakota State University, Fargo, ND, USA

Saqib Mukhtar and Sergio Capareda

Biological and Agricultural Engineering Department, Texas AEM University, TAMU College station, TX, USA

\section{References}

[1] IPCC. Chapter 2: Changes in atmospheric constituents and in radiative forcing. In Climate Change 2007: The Physical Science Basis; Contribution of Working Group I to the $4^{\text {th }}$ Assessment Report of the Intergovernmental Panel on Climate Change; Cambridge University Press: New York, NY, USA; 2007.

[2] Burns RT, Li H, Xin H, Gates RS, Overhults DG, Earnest J, Moody L. Greenhouse Gas (GHG) Emissions from Broiler Houses in the Southeastern United States. Presented at the ASABE Annual International Meeting, St. Joseph, MI, USA, 29 June-2 July 2008; Paper No. 084649.

[3] USEPA. United States Environmental Protection Agency. Inventory of U.S. Greenhouse Gas Emissions and Sinks. Report Number EPA 430-R-08-005; U.S. Government Printing Office: Washington, DC, USA, 2008.

[4] Crosson, P., L. Shalloo, D. O’Brien, G. J., Lanigan, P. A. Foley, and T. M. Boland. 2011. A review of whole farm systems models of greenhouse gas emisisons from beef and dairy cattle production systems. Animal Feed Science Technology. 166-167: 29-45.

[5] Chadwick, DR, Pain, BF, Brookman, SKE. Nitrous oxide and methane emissions following application of animal manures to grassland. Journal Environmental Quality 2000; 29, 277-287.

[6] Naqvi SMK, Sejian V. 2010. Global Climate Change: Role of Livestock. Asian Journal of Agricultural Sciences 2010; 3(1) 19-25.

\footnotetext{
${ }^{*}$ Corresponding Author
} 
[7] Sejian V, Naqvi SMK. 2012. Livestock and Climate Change: Mitigation Strategies to Reduce Methane Production. Available at http://cdn.intechopen.com/pdfs/30637/InTechLivestock_and_climate_change_mitigation_strategies_to_reduce_methane_production.pdf [accessed 5.15.12].

[8] Mukhtar S. Manure Production and Characteristics: Its Importance to Texas and AnimalFeeding Operation; University libraries digital Texas A\&M: College Station, TX, USA, 2009.Available online:

http://tammi.tamu.edu/pubs.html (accessed on 05/02/12).

[9] Sedorovich, DM, Rotz CA, Richard TL. Greenhouse Gas Emissions from Dairy Farms. In: roceedings ASABE Annual International Meeting, St. Joseph, MI, USA, 17-20 June 2007; Paper o. 074096.

[10] Hansen MN, Kai P, Moller HB. Effects of anaerobic digestion and separation of pig slurry on odor emission. Applied engineering in agriculture 2006; 22(1) 135-139.

[11] Jungbluth T, Hartung E, Brose G. Greenhouse emissions from animal houses and manure stores. Nutrients Cycling Agroecosystem 2001; 60 133-145.

[12] Kinsman R, Saucer FD, Jackson HA, Wolynetz MS. Methane and carbon dioxide emissions from dairy cows in full lactation monitored over a six-month period. Journal Dairy Science 1995; 78 2760-2766.

[13] Amon, B, Amon T, Boxberger J, Alt Ch. Emissions of $\mathrm{NH}_{3}, \mathrm{~N}_{2} \mathrm{O}$, and $\mathrm{CH}_{4}$ from dairy cows housed in a farmyard manure tying stall (housing, manure storage, manure spreading). Nutrient Cycling Agroecosyst. 2001; 60 103-113.

[14] Ngwabie NM, Jeppsson KH, Nimmermark S, Swensson C, Gustafsson G. Multilocation measurements of greenhouse gases and emission rates of methane and ammonia from a naturally-ventilated barn for dairy cows. Biosystems Engineering 2009; 103 68-77.

[15] Crutzen PJ, Aselmann I, Seiler W. Methane production by domestic animals, wild ruminants, other herbivorous fauna and humans. Tellus 1986; 38B 271-284.

[16] Gibbs, M and Johnson, D. E. Methane emissions from digestive process of livestock. International anthropogenic methane emissions: Estimates for 1990. EPA 230 R-93-010, pp. 2-1-2-44, 1994.

[17] Fiedler AM, Muller HJ. Emissions of ammonia and methane from a livestock building natural cross ventilation. Meteorologische Zeitschrift 2011; 20(1) 059-065.

[18] Sun H, Trabue SL, Scoggin K, Jackson WA, Pan Y, Zhao Y, Malkina IL, Koziel JA, Mitloehner FM. Alcohol, volatile fatty acid, phenol, and methane emissions from dairy cows and fresh manure. J. Environ. Qual. 2008; 37 615-622.

[19] Zoe L, Chen D, Mei B, Naylor T, Griffith D, Hill J, Denmead OT, McGinn S, Edis R. Measurement of greenhouse gas emissions from Australian feedlot beef production using open-path spectroscopy and atmospheric dispersion modeling. Aust. J. Exp. Agric. 2008, 48 244-247.

[20] McGinn SM, Chen D, Loh Z, Hill J, Beauchemin KA, Denmead OT. Methane emissions from feedlot cattle in Australia and Canada. Aust. J. Exp. Agric. 2008, 48 183-185. 
[21] Van Haarlem, RP, Desjardins RL, Gao, Z, Flesch TK, Li, X. Methane and ammonia emissions from a beef feedlot in western Canada for a twelve-day period in the fall. Can. J. Anim.Sci. 2008; 88 641-649.

[22] Phetteplace HW, Johnson DE, Seidl AF. Greenhouse gas emissions from simulated beef and dairy livestock systems in the United States. Nutr. Cycling Agroecosyst. 2001; 60 99-102.

[23] Harper LA, Denmead OT, Freney JR, Byers FM. Direct measurements of methane emissions from grazing and feedlot cattle. Journal Animal Science 1999; 771392 1401.

[24] Groot Koerkamp PWG, Uenk, GH. Climatic conditions and aerial pollutants in and emissions from commercial animal production systems in the Netherlands. In: Proceedings of International Symposium Ammonia and Odour Control from Animal Facilities. 6-10.10.1997, Vinkeloord, pp. 139-144.

[25] Gallmann E, Hartung E, Jungbluth T. 2000. Assessment of two pig housing and ventilation systems regarding indoor air quality and gas emissions - diurnal and seasonal effects. In: prceedings Ag Eng 2000, Paper 00-FB-002. 2000, Warwick, England, pp. 140-141.

[26] Gallmann E, Hartung E, Jungbluth T. Long-term study regarding the emission rates of ammonia and greenhouse gases from different housing systems for fattening pigs - final results. In: Proceedings of the International Symposium on Gas and Odor Emissions from Animal Production, Horsens, Denmark. CIGR, 2003, pp. 122-130.

[27] Sharpe RR, Harper LA., Simmons JD. Methane emissions from swine houses in North Carolina. Chemosphere Global Change Science 2001; 3 1-6.

[28] Rahman S, Lin D, Zhu J. Greenhouse gas (GHG) emissions from mechanically ventilated deep pit swine gestation operation. Journal Civil Engineering 2012; 2 104, doi:10.4172/2165-784x.1000104.

[29] Dong H, Zhu H, Shang B, Kang H, Zhu H, Xin H. Greenhouse gas emissions from swine barns of various production stages in suburban Beijing, China. Atmospheric Environment 2007; 41 2391-2399.

[30] Hahne J, Hesse D, Vorlop KD. Trace gas emissions from fattening pig housing. Landtechnik 1999; 54 (3) 180-181.

[31] Borhan MS, Capareda S, Mukhtar S, Faulkner WB, McGee R, Parnell Jr CB. Determining Seasonal Greenhouse Gas Emissions from Ground Level Area Sources in a Dairy Operation in Central Texas. J. Air and Waste Management 2011; 61 786795.

[32] Borhan , MS, Capareda S, Mukhtar S, Faulkner WB, McGee R, Parnell Jr CB. Greenhouse Gas Emissions from Ground Level Area Sources in Dairy and Cattle Feedyard Operations. Atmosphere 2011; 2 303-329.

[33] Bjorneberg DL, Leytem, AB, Westermann T, Griffiths PR, Shao L, Pollard MJ. Measurement of atmospheric ammonia, methane, and nitrous oxide at a concentrated 
dairy production facility in southern Idaho using open-path FTIR spectrometry. Transactions of ASABE 2009; 52(5) 1749-1756.

[34] Zhu Z, Dong H, Zhou Z. Ammonia and greenhouse gas in a dairy cattle building with daily manure collection system. In: Proceedings Annual International Meeting, ASABE St. Joseph MI; 2011; Paper no 1110761.

[35] Leytem AB, Bjorneberg DL, Dungan RS. Emissions of ammonia and greenhouse gas from dairy production facilities in southern Idaho. Western Nutrients Management Conference, Reno Nevada 2011; 9 29-34

[36] Leytem AB, Dungann RS, Bjorneberg DL, Koehn AC. Emissions of ammonia, carbon dioxide, and nitrous oxide from dairy cattle housing manure management systems. Journal Environmental Quality 2010 40:1383 - 1394. doi: 10.2134/jeq2009.0515.

[37] Hensen A, Groot TT, van den Bulk WCM, Vermeulen AT, Olesen JE, Schelde K. Dairy farm $\mathrm{CH}_{4}$ and $\mathrm{N}_{2} \mathrm{O}$ emissions from square meter to full farm scale. Agric. Ecosyst. Environ 2006; 112 146-152.

[38] Guarrino, M., Fabbri, C., Navarotto, P., et al., 2003. Ammonia, methane and nitrous oxide emissions and particulate matter concentration in two different buildings for fattening pigs. In: Proceedings of the International Symposium on Gas and Odor Emissions from Animal Production, Horsens, Denmark. CIGR, pp. 140-149.

[39] Baudouin, N, Laitat M, Vandenheede, M. Emissions of ammonia, nitrous oxide, methane, carbon dioxide and water vapor in the raising of weaned pigs on straw-based and sawdust-based deep litters. Animal Research 2003; 52 299-308.

[40] Osada T, Rom HB, Dahl P. Continuous measurement of nitrous oxide and methane emissions in pig units by infrared photoacoustic detection. Transactions of the ASAE 1998; 41 (4) 1109-1114.

[41] Sneath RW, Chadwick DR, Phillips VR, Pain BF, A UK inventory of Methane emissions from farmed livestock. Silsoe Research Institute, Wrest Park, Silsoe, Bedford MK45 4HS, UK Commissions WA0604 and WA0605; 1997.

[42] Su J-J, Liu B-Y, Chang Y-C. Emission of greenhouse gas from livestock waste and wastewater treatment in Taiwan. Agriculture, Ecosystems and Environment 2003; 95 253-263.

[43] Saggar S, Bhandral R, Hedley CB, Luo J. A review of emissions of methane, ammonia, and nitrous oxide from animal excreta deposition and farm effluent application in grazed pastures. New Zealand J. Agric. Res. 2004; 47 513-544.

[44] Le Mer JL, Roger P. Production, oxidation, emission and consumption of methane by soils: A review. European Journal of Soil Biology 2001; 7 25-50.

[45] Wulf S, Maeting M, Bergmann S, Clemens J, 2001: Simultaneous measurement of $\mathrm{NH}_{3}$, $\mathrm{N}_{2} \mathrm{O}$ and $\mathrm{CH}_{4}$ to assess efficiency of trace gas emission abatement after slurry application. Phyton 2001; 41 131-142.

[46] IPCC 2001: Technical summary. In: Houghton, J. T.; Ding, Y.; Grigg, D. J.; Noguer, M.; van der Linden, P. J.; Dai, X.; Maskell, K.; Johnson, C. A. ed. Climate change 2001: The 
scientific basis. Contributions of Working Group I of the Intergovernmental Panel on Climate Change. Cambridge, Cambridge University Press.

[47] Robertson G P, Tiedje JM. Nitrous oxide sources in aerobic soils; nitrification, enitrification and other biological processes. Soil Biology and Biochemistry 1987; 19: 187-193.

[48] Velthof GL, Kuikman PJ, Oenema O. Nitrous oxide emission from animal manures applied to soil under controlled conditions. Biol Fertil Soils 2003; 37 221-230.

[49] Ball, B. C, Horgan GW, Clayton H, Parker J P. 1997: Spatial variability of nitrous oxide fluxes and controlling soil and topographic properties. Journal of Environmental Quality 1997; 26 1399-1409.

[50] Castaldi S, Smith KA. 1998: Effect of cycloheximide on $\mathrm{N}_{2} \mathrm{O}$ and $\mathrm{NO}_{3}^{-}$production in a forest and agricultural soil. Biology and Fertility of Soils 1998; 27 27-34.

[51] MacKenzie AF, Fan MX, Cadrin F. Nitrous oxide emission in three years as affected by tillage, corn-soybean-alfalfa rotations, and nitrogen fertilization. Journal of Environmental Quality 1998; 27 698-703.

[52] Dobbie KE, McTaggart IP, Smith KA. 1999: Nitrous oxide emissions from intensive agricultural systems: variations between crops and seasons, key driving variables, and mean emission factors. Journal of Geophysics Research 1999; 104 26891-26899

[53] Dobbie KE, Smith KA. The effect of temperature, water-filled pore space, and land use on N2O emissions from an imperfectly drained gleysol. European Journal of Soil Science 2001; 52 667-673.

[54] Staley TE, Caskey WH, Boyer DG. Soil denitrification and nitrification potentials during the growing season relative to tillage. Soil Science Society of America Journal 1990; 54 $1602-1608$.

[55] Hansen S, Maehlum JE, Bakken LR. $\mathrm{N}_{2} \mathrm{O}$ and $\mathrm{CH}_{4}$ fluxes in soil influenced by fertilization and tractor traffic. Soil Biology and Biochemistry 1993; 25 621-630.

[56] Christensen S, Ambus P, Arah J, Clayton H, Galle B, Griffith D, Hargreaves K, Klemedtsson, L, Lind A-M., Maag M, Scott A, Skiba U, Smith K, Welling M, Wienhold F. Nitrous oxide emission from an agricultural field: comparison between measurements by flux chamber and micrometeorological techniques. Atmospheric Environment 1996; 30 (24) 4183-4190.

[57] Hudson N, Ayoko GA. Odour sampling 1: Physical chemistry considerations. Bioresource Technology 2008; 99 3982-3992

[58] Eklund B, Balfour W, Schmidt C. 1985. Measurement of fugitive volatile organic emission rates. Environmental Progress 1985; 4 (3) 199-202.

[59] Gholson AR, Albriton J.R, Yayanti RKM. Evaluation for the Flux Chamber Method for Measuring Volatile Organic Emissions from Surface Impoundments; Project Summary EPA/600/S3-89/008; U.S. Environmental Protection Agency: Washington, DC, USA, 1989. 
[60] Parker DB, Caraway EA, Rhoades MB, Cole NA, Todd RW, Casey KD. Effect of wind tunnel air velocity on VOC flux from standard solutions and CAFO manure/wastewater. Transactions ASABE 2010; 53 831-845.

[61] Hudson N, Ayoko GA, Dunlop M, Duperouzel D, Burrell D, Bell K, Gallagher E, Nicholas $\mathrm{P}$, and N. Heinrich N. Comparison of odor emission rates measured from various sources using two sampling devices. Bioresource Technology 2009; 100(1) 118124.

[62] Kienbusch MR. 1986. Measurement of Gaseous Emission Rates from Land Surfaces Using an Emission Isolation Flux Chamber - User's Guide. EPA/600/8-86/008. Washington, DC: U.S. Environmental Protection Agency.

[63] Parker D, Ham J, Woodbury Lingshuang BC, Mindy S, Trabue S, Casey K, Cole A. 2012. Standardization of flux chamber and wind tunnel flux measurements for quantifying volatile organic compound and ammonia emissions from area sources at animal feeding operations. Atmospheric Environment In press.

[64] Melse RW, Ognik NWM, Rulkens WH. Air treatment techniques for abatement of emissions from intensive livestock production. The Open Agriculture Journal 2009; 3 612.

[65] Estelles F, Melse RW, Ogink NWM, Calvet S. Evaluation of the NH3 removal efficiency of an acid packed bed scrubber using two methods: a case study. Transaction of ASABE 2011; 54(5) 1905-1912

[66] Manuzon RB, Zhao LY, Keener HM, Darr MJ. A prototype acid spray scrubber for absorbing ammonia emissions from exhaust fans of animal buildings. Transactions of the ASABE 2007; 50(4) 1395-1407.

[67] Zhao Y, Aarnink AJA, Hofschreudera P, Groot Koerkamp PWG. Evaluation of an impaction and a cyclone pre-separator for sampling high $\mathrm{PM}_{10}$ and $\mathrm{PM}_{2.5}$ concentrations in livestock houses. Aerosol Science 2009; 40868 - 878.

[68] Pedersen S, Blanes-Vidal V, Joergensen H, Chwalibog A, Haeussermann A, Heetkamp MJW, Aarnink AJA. Carbon Dioxide Production in Animal Houses: A literature Review. Agricultural Engineering338 International: the CIGR Ejournal.2008 Manuscript BC 08008 , Vol. X.

[69] Licht LA, Miner JR. 1978. A scrubber to reduce livestock confinement building odors. ASAE Paper No. 78-203, St. Joseph, Mich.: ASAE; 1978.

[70] Zhao LY, Riskowski GL, Stroot P, Robert M, Heber AJ. Development of a wet scrubber to reduce dust and gas emissions from swine buildings. ASAE Paper No. 014075. St. Joseph, Mich.: ASAE; 2001.

[71] Melse RW, Ogink NWM. Air scrubbing techniques for ammonia and odor reduction at livestock operations: review of on-farm research in the Netherlands. Transactions of the ASAE 2005; 48(6) 2303-2313.

[72] Chen L, Hoff S, Cai L, Koziel JA, Zelle B. 2009. Evaluation of wood chip-based biofilters to reduce odor, hydrogen sulfide, and ammonia from swine barn ventilation air. Journal of the Air \& Waste Management Association 2009; 59: 520-530. 
[73] Aarnink AJ, Le PD, Ognik NWM, Becker PM, Verstegen MWA. Odor for animal production facilities: Its relationship to diets. Nut Res Rev. 2005; 18(1) 3-30.

[74] Hahne J, Krause K-H, Munack A, Vorlop K-D. Environmental engineeringreduction of emissions. In Yearbook Agricultural Engineering, 35-43. Matthies EHHJ, Meier F (eds.) Muenster, Germany: VDMA Landtechnik, VDI-MEG, KTBL; 2003.

[75] Hahne J, Krause K-H, Munack A, Vorlop K-D. Vorlop 2005. Bio-engineering, environmental engineering. In Yearbook Agricultural Engineering, 183-188.Harms H-H, Meier F (eds.) Muenster, Germany: VDMA Landtechnik, VDI-MEG, KTBL; 2005

[76] Milleu Partners. 2007. Home page: http://www.milieupartners.nl/index.htm. Last accessed on May 25, 2012.

[77] Shah SB, Westerman PW, Munilla RD, Adcock ME, Baughman GR. Design and evaluation of a regenerating scrubber for reducing animal house emissions. Transactions ASABE 2008; 51(1) 243-250.

[78] Melse RW, Timmerman M. Sustainable intensive livestock production demands manure and exhaust air treatment technologies. Bioresource Technology 2009; 100 5506-5511

[79] Zhao Y, Aarnink AJA, de Jong MCM, Ognik NWM, Groot Koerkamp PWG. Effectiveness of multi-stage scrubbers in reducing emissions of air pollutant from pig houses. Transactions ASABE 2011; 54(1) 285-293.

[80] Zhang Y, Polakow JA, Wang X, Riskowski GL, Sun Y, Ford SE. 2001. An aerodynamic deduster to reduce dust and gas emissions from ventilated livestock facilities. In: Livestock Environment VI: In: Proceedings of the 6th International Symposium. pp. 596-603. Kentucky; 2001.

[81] Ocfemia K, Zhang Y, Tan Z. Ammonia absorption in a vertical sprayer at low ammonia partial pressures. Transactions of the ASABE 2005; 48(4) 1561-1566.

[82] Feddes, J, Edeogu I, Bloemendaal B, Lemay S, Coleman R. 2001. Odor reduction in a swine barn by isolating the dunging area. In: Stowell, R. R, Bucklin R, Bottcher R.W(eds): Livestock Environment VI: proceedings of the 6th International Symposium. ASAE, Louisville, Kentucky; 2001.

[83] Burgess JE, Parsons SA, Stuetz RM. Developments in odour control and waste gas treatment biotechnology: A review. Biotechnology Advances 2001; 19 35-63.

[84] Schmidt DR, Janni KA, Nicolai RE. 2004. Biofilter Design Information BAE \#18, University of Minnesota, Department of Biosystems and Agricultural Engineering, $<$ http://www.manure. umn.edu/assets/baeu18.pdf > accessed 05.15.12

[85] Elenbass A, Zhao LY, Young Y, Wang X, Riskowski GL, Ellis M, Heber AJ. Effects of room ozonation on air quality and pig performance. Transaction ASAE 2005; 48(3) 11671173.

[86] Wang L, Oviedo-Rondón EO, Small J, Liu Z, Sheldon BW, Havenstein GB, Williams MC. Farm-scale evaluation of ozonation for mitigating ammonia 
concentrations in broiler houses. Journal of Air and Waste Management Association 2010; 60 789-796.

[87] Powers W. Odor control for livestock systems. Journal of Animal Science 1999; 77: 169176.

[88] Hansen KH, Angelidaki I, Ahring BK. Anaerobic digestion of swine manure: Inhibition by ammonia. Water research 1998; 32(1) 5-12.

[89] Hobbs PJ, Pain BF, Kay RM, Lee PA. Reduction of odorous compounds in fresh pig slurry by dietary control of crude protein. Journal of the Science of Food and Agriculture 1996; 71: 508-514.

[90] Sutton AL, Kephart KB, Verstegen MWA, Canh TT, Hobbs PJ. Potential for reduction of odorous compounds in swine manure through diet modification. Journal of Animal Science 1999; 77 430-439.

[91] Castillo AR, Kebreab E, Beever DE. The effect of protein supplementation on nitrogen utilisation in grass silage diets by lactating dairy cows. Journal of Animal Science 2001; 79 247-253.

[92] Kendall DC, Lemenager KM, Richert BT, Sutton AL, Frank JW, Belstra BA, and Bundy D. (1998). Effects of Intact Protein Diets Versus Reduced Crude Protein Diets Supplemented with Synthetic Amino Acids on Pig Performance and Ammonia Levels in Swine Buildings. Swine Day1998; 141-146.

[93] Kebreab E, Strathe A, Fadel J, Moraes L, France J. 2010. Impact of dietary manipulation on nutrient flows and greenhouse gas emissions in cattle. R. Bras. Zootec 2010; 39 458464.

[94] Hao X, Benke MB, Gibb DJ, Stronks A, Travis G, McAllister TA. Effects of dried distillers' grains with solubles (wheat-based) in feedlot cattle diets on feces and manure composition. Journal of Environmental Quality 2009; 38: 1709-1718.

[95] Kebreab E, Starthe A, France J, Beever DE, Castolo AR. Nitrogen pollution by dairy cows and its mitigation. Nutrient Cycling in Agroecosystems 2001; 60 275-285.

[96] Eckard R J, Grainger C, and C. de Klein CAM. Options for the abatement of methane and nitrous oxide from ruminant production: A review. Livestock Science 2010; 130(1-3) 47-56.

[97] Boadi D, Benchaar C, Chiquette J, Massé D. Mitigation strategies to reduce enteric methane emissions from dairy cows: update review. Available at: http://classes.uleth.ca/200901/biol4500a/Readings/Beauchemin1.pdf; 2004 [accessed 5.20.12].

[98] Sejian V, Lakritz J, Ezeji T, Lal R. Forage and Flax seed impact on enteric methane emission in dairy cows. Research Journal of Veterinary Sciences 2011; 4(1) 1-8.

[99] Beauchemin KA, Kreuzer M, O'Mara F, McAllister TA. Nutritional management for enteric methane abatement: a review. Australian Journal of Experimental Agriculture $2008 ; 48(1-2) 21-27$. 
[100] Cahn TT, Sutton AL, Aarnink AJA, Verstegen MWA, Schrama JW, Bakker GCM. Dietary carbohydrates alter the fecal composition and $\mathrm{pH}$ and the ammonia emission from slurry of growing pigs. Journal Animal Science 1998; 76: 1887-95.

[101] Kim IB, Ferket PR, Powers WJ, Stein HH, Van Kempen TATG. Effects of different dietary acidifier sources of calcium and phosphorus on ammonia, methane and odorant emission from growing finishing pigs. Asian-austral as Journal Animal Science 2004; 17(8): 1131-8.

[102] Van Middelkoop JH, Van Harn J. The influence of reduced protein levels in broiler feed on NH3 emissions. Transl Silsoe Res Institute 1998; 66: 34.

[103] Elwinger K, Svensson L. Effect of dietary protein content, litter and drinker type on ammonia ammonia emission from broiler houses. J Agricultural Engineering Research 1996; 64(3) 197-208.

[104] Angel R, Powers W, Applegate T. Diet impacts for mitigating air emissions from poultry. In: Proceedings of the 8th International Livestock Symposium (ILES VIII), Iguassu Falls, August 31 - September 4, 2008.

[105] Van Duinkerken G, André G, Smits MCJ, Monteny GJ, Lebek LBJ. Effect of rumendegradable protein balance and forage type on bulk milk urea concentration and emission of ammonia from dairy cow houses. J Dairy Science 2005; 88: 1099-112.

[106] Smits MCJ, Valk H, Elzing A, Keen A. Effect of protein nutrition on ammonia emission from a cubicle house for dairy cattle. Livest Prod Sci 1995; 44(6) 147-56.

[107] Velthof GL, Nelemans JA, Oenema O, Kuikman PJ. Gaseous nitrogen and carbon losses from pig manure derived from different diets. Journal Environmental Quality 2005; 34 698-706.

[108] VanderZaag, AC, Gordon RJ, Glass VM, Jamiesson RC. Floating covers to reduce gas emissions from liquid manure storage: A review. Transactions of the ASABE 2008; 24(5) 657-671.

[109] de Klein CAM. Mitigating $\mathrm{N}_{2} \mathrm{O}$ emissions from agriculture - an overview of the science. In: Proceedings of the Trace Gas Workshop, 18-19 March 2004, Wellington, New Zealand; 2004.

[110] Clemens J, Ahlgrimm HJ. Greenhouse gases from animal husbandry: mitigation options. Nutrient Cycling in Agroecosystems 2001; 60 287-300.

[111] Brink C, Kroeze C, Klimont Z. Ammonia abatement and its impact on emissions of nitrous oxide and methane: Part 2. Application for Europe. Atmospheric Environment 2001; 25 6313-25.

[112] Misselbrook T H, Chadwick DR, Pain BF, Headon DM. Dietary manipulation as a means of decreasing $\mathrm{N}$ losses and methane emissions and improving herbage $\mathrm{N}$ uptake following application of pig slurry to grassland. The Journal of Agricultural Science 1998; 130 183-191.

[113] Weier KL, Doran JW, Power JF, Walters DT. Denitrification and the dinitrogen nitrousoxide ratio as affected by soil-water, available carbon, and nitrate. Soil Science Society of America Journal 1993; 57 66-72. 
[114] Arnink AJA, Elzing A. Dynamic model for ammonia volatilization in housing with partially slatted floors, for fattening pigs. Livest Prod Sci 1998; 53(3) 153-69.

[115] Monteny GJ, Schulte DD, Elzing A, Lamaker EJJ. A conceptual mechanistic model for the ammonia emissions from free stall cubicle dairy cow houses. Transactions ASAE 1999; 41 193-201.

[116] Aarnink AJA, Schrama JW, Heetkamp MJW, Stefanowska J, Huynh TTT. Temperature and body weight affect fouling of pig pens. Journal Animal Science 2006; 84 2224-31.

[117] Hilhorst, MA, Mele RW, Willers HC, Groenestein CM, Monteny GJ. Effective strategies to reduce methane emissions from livestock. ASAE, Paper no 01-4070; 2001. 